Argonne

\title{
Well-to-Wheels Analysis of Compressed Natural Gas and Ethanol from Municipal Solid Waste
}

Energy Systems Division 


\section{About Argonne National Laboratory}

Argonne is a U.S. Department of Energy laboratory managed by UChicago Argonne, LLC

under contract DE-AC02-06CH11357. The Laboratory's main facility is outside Chicago, at 9700 South Cass Avenue, Argonne, Illinois 60439. For information about Argonne

and its pioneering science and technology programs, see www.anl.gov.

\section{DOCUMENT AVAILABILITY}

Online Access: U.S. Department of Energy (DOE) reports produced after 1991 and a growing number of pre-1991 documents are available free via DOE's SciTech Connect (http://www.osti.gov/scitech/)

Reports not in digital format may be purchased by the public from the National Technical Information Service (NTIS):

U.S. Department of Commerce

National Technical Information Service

5301 Shawnee Rd

Alexandria, VA 22312

www.ntis.gov

Phone: (800) 553-NTIS (6847) or (703) 605-6000

Fax: (703) 605-6900

Email: orders@ntis.gov

Reports not in digital format are available to DOE and DOE contractors from the Office of Scientific and Technical Information (OSTI):

U.S. Department of Energy

Office of Scientific and Technical Information

P.O. Box 62

Oak Ridge, TN 37831-0062

www.osti.gov

Phone: (865) 576-8401

Fax: (865) 576-5728

Email: reports@osti.gov

\section{Disclaimer}

This report was prepared as an account of work sponsored by an agency of the United States Government. Neither the United States Government nor any agency thereof, nor UChicago Argonne, LLC, nor any of their employees or officers, makes any warranty, express or implied, or assumes any legal liability or responsibility for the accuracy, completeness, or usefulness of any information, apparatus, product, or process disclosed, or represents that its use would not infringe privately owned rights. Reference herein to any specific commercial product, process, or service by trade name, trademark, manufacturer, or otherwise, does not necessarily constitute or imply its endorsement, recommendation, or favoring by the United States Government or any agency thereof. The views and opinions of document authors expressed herein do not necessarily state or reflect those of the United States Government or any agency thereof, Argonne National Laboratory, or UChicago Argonne, LLC. 


\section{Well-to-Wheels Analysis of Compressed Natural Gas and Ethanol from Municipal Solid Waste}

by

Uisung Lee, Jeongwoo Han, and Michael Wang

Energy Systems Division, Argonne National Laboratory

October 2016 



\section{CONTENTS}

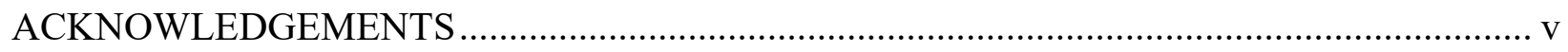

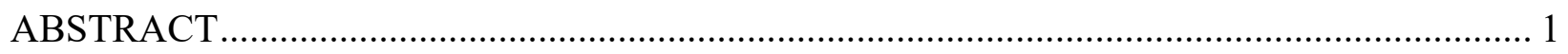

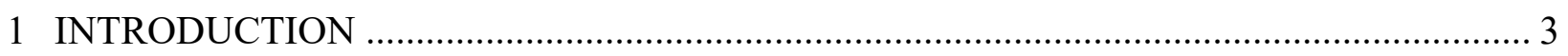

2 ANALYSIS APPROACH AND SYSTEM BOUNDARY …......................................... 5

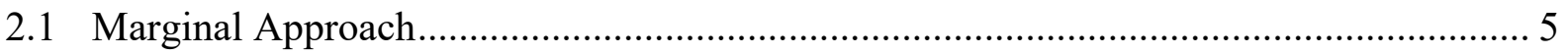

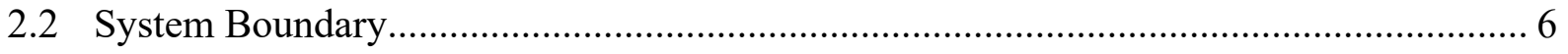

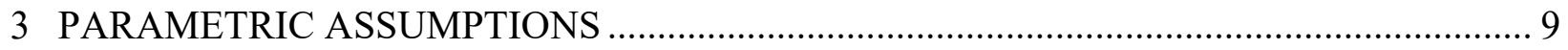

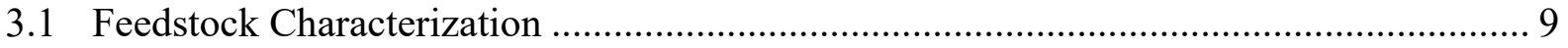

3.2 Counterfactual Scenario: Waste Landfill .................................................................. 9

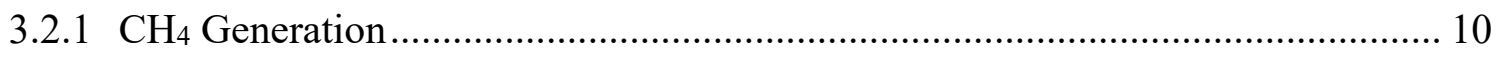

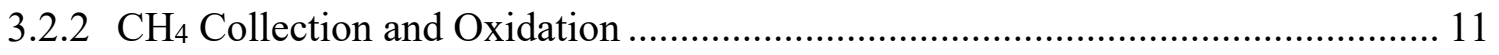

3.2.3 Lifetime $\mathrm{CH}_{4}$ Generation, Collection, and Emissions Profiles and LFG Collection Efficiencies.................................................................................. 14

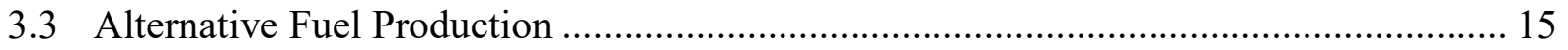

3.3.1 CNG Production Using Anaerobic Digestion............................................... 15

3.3.2 Ethanol Production Using Fermentation................................................... 17

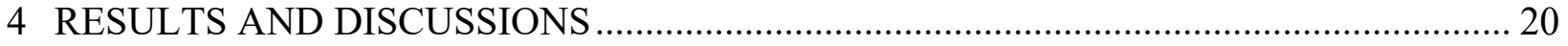

4.1 GHG Emissions Per Dry Ton of Waste by WTE Pathways Compared With Counterfactual Scenarios ...................................................................................... 20

4.2 WTW GHG Emissions of WTE Pathways............................................................. 23

4.3 WTW Fossil Fuel Consumption of WTE Pathways................................................ 24

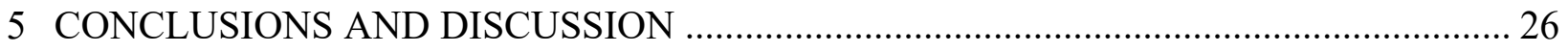

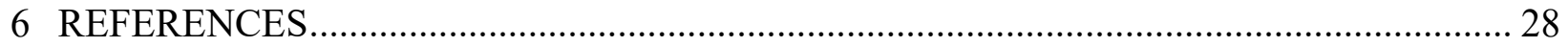

\section{FIGURES}

1 LCA Approach of WTE Pathways: a) EPA's Approach, and b) Marginal Approach .............. 6

2 System Boundary of the Counterfactual Scenario ......................................................... 7

3 System Boundary of the WTE Pathways: a) CNG and LNG Production via Anaerobic Digestion and b) Ethanol Production via Fermentation ..................................................... 8

4 LFG Collection and Cover Installation Plans of a Landfill Cell for Active and Moderate LFG Collection Cases

5 Simulation Results of Methane Generation, Collection, Oxidization, and Emission from Waste Landfills with a) Active LFG Collection and b) Moderate LFG Collection 15 


\section{FIGURES (CONT.)}

6 GHG Emissions for CNG from Food Waste AD and Ethanol from Yard Trimmings Fermentation Compared with Counterfactual Scenarios

7 WTW GHG Emissions for CNG from Food Waste AD and Ethanol from Yard Trimmings Fermentation Compared with Conventional NG and Gasoline Pathways

8 WTW Fossil Fuel Consumption for CNG from Food Waste AD and Ethanol from Yard Trimmings Fermentation Compared with Conventional NG and Gasoline Pathways...

\section{TABLES}

1 Discarded Solid Waste Composition in the United States in 2013 ...................................... 9

2 Degradable Organic Carbon and Reaction Constant........................................................ 11

3 Collection Efficiency by Landfill Operation Phase ....................................................... 13

4 Key Products, Emissions and Energy Requirements of the AD Process Using Food

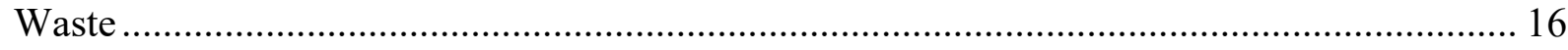

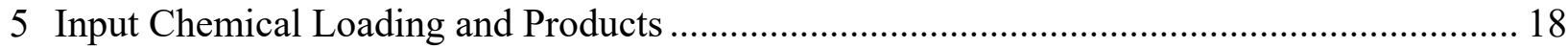

6 Carbon Fate from Waste and GHG Emissions Contribution by Each Stage in the Counterfactual Scenarios and the WTE Pathways 


\section{ACKNOWLEDGEMENTS}

This research effort was supported by the Bioenergy Technology Office (BETO) of the Office of Energy Efficiency and Renewable Energy of the U.S. Department of Energy under contract DE-AC02-06CH11357. We are grateful to Daniel Fishman, Mark Philbrick, and Brandon Hoffman of BETO for their support and guidance. We gratefully acknowledge the support and technical inputs from Bruce Knapp of Advanced Disposal Services Orchard Hills Landfill, George Armstrong of Clinton Landfill, Katry Martin of St. Landry Parish Landfill, Mark Madden of Anchorage Regional Landfill, Jason Munyan of Cherry Island Landfill, Robert Bobeck of Riverview Land Preserve, John Londres of Pennsauken Sanitary Landfill, Pantelis Panteli of Chautauqua County Landfill, and Douglas Morris of Crow Wing County Landfill. We also appreciate the helpful comments and inputs from Brian Helmowski of the California Department of Resources Recycling and Recovery and Ignasi Palou-Rivera of LanzaTech. The authors are solely responsible for the technical contents of this paper. 


\title{
WELL-TO-WHEELS ANALYSIS OF COMPRESSED NATURAL GAS AND ETHANOL FROM MUNICIPAL SOLID WASTE
}

\author{
Authors: Uisung Lee, Jeongwoo Han and Michael Wang \\ Systems Assessment Group, Energy Systems Division, Argonne National Laboratory, \\ 9700 South Cass Avenue, Argonne, IL 60439, United States
}

\begin{abstract}
The amount of municipal solid waste (MSW) generated in the United States was estimated at 254 million wet tons in 2013, and around half of that generated waste was landfilled. There is a huge potential in recovering energy from that waste, since around $60 \%$ of landfilled material is biomass-derived waste that has high energy content. In addition, diverting waste for fuel production avoids huge fugitive emissions from landfills, especially uncontrolled $\mathrm{CH}_{4}$ emissions, which are the third largest anthropogenic $\mathrm{CH}_{4}$ source in the United States.

Lifecycle analysis (LCA) is typically used to evaluate the environmental impact of alternative fuel production pathways. LCA of transportation fuels is called well-to-wheels (WTW) and covers all stages of the fuel production pathways, from feedstock recovery (well) to vehicle operation (wheels). In this study, the Greenhouse Gases, Regulated Emissions, and Energy Use in Transportation (GREET ${ }^{\circledR}$ ) model developed by Argonne National Laboratory is used to evaluate WTW greenhouse gas (GHG) emissions and fossil fuel consumption of waste-derived fuels. Two waste-to-energy (WTE) pathways have been evaluated - one for compressed natural gas $(\mathrm{CNG})$ production using food waste via anaerobic digestion, and the other for ethanol production from yard trimmings via fermentation processes. Because the fuel production pathways displace current waste management practices (i.e., landfilling waste), we use a marginal approach that considers only the differences in emissions between the counterfactual case and the alternative fuel production case.

The results show that the renewable $\mathrm{CNG}$ from food waste can reduce GHG emissions by $28-157 \%$ compared with CNG from fossil sources, while the ethanol from yard trimmings waste can reduce GHG emissions by $52-146 \%$ compared with gasoline. Most of the reduction results from avoiding the emissions associated with the counterfactual scenario, mainly uncontrolled $\mathrm{CH}_{4}$ emissions from landfills. Because waste-derived fuels are non-fossil fuels, WTW fossil fuel consumption is also reduced dramatically: by $106 \%$ for the CNG produced from food waste compared with that of natural gas, and $74 \%$ for ethanol produced from yard trimmings compared with that of gasoline. However, the results depend on the conditions of both the counterfactual scenarios and the alternative fuel production scenarios. In order to refine the results, further
\end{abstract}


investigation is needed for the parameters of landfill gas (LFG) emissions, which are subject to many uncertainties. 


\section{INTRODUCTION}

In 2013, the amount of municipal solid waste (MSW) generated in the United Sates was estimated at 254 million wet tons, and only $34 \%$ of generated waste was recycled (US EPA 2015). Of the remaining $66 \%$ of generated waste, $80 \%$ was discarded in landfills, while $20 \%$ was combusted or incinerated. In addition to several local environmental issues, such as soil and groundwater pollution, landfilling MSW contributes to global warming significantly because it is considered to be a critical source of greenhouse gas (GHG) emissions. $\mathrm{CH}_{4}$ emission from waste landfills alone was estimated at $148 \mathrm{MMT}$ (million metric ton) $\mathrm{CO}_{2}$ equivalent $\left(\mathrm{CO}_{2} \mathrm{e}\right)$ in the United States in 2013, which makes it the third largest anthropogenic $\mathrm{CH}_{4}$ source (US EPA 2016).

Food waste and yard trimmings, part of the organic fraction of MSW (OFMSW), can be good feedstocks for various waste-to-energy (WTE) pathways because they have high energy content, and their properties are very similar to biomass feedstocks commonly used for fuel production. Even with these advantages, however, most waste has been landfilled due to economic and technical constraints. Recent research on converting organic solid waste into fuels, including anaerobic digestion (AD), fermentation, gasification, and hydrothermal liquefaction, has shown improved fuel yields due to new technical advancements. In addition, in 2014, US Environmental Protection Agency (EPA) approved renewable compressed and liquefied natural gas (CNG and LNG) and electricity from biogas derived from separated MSW for generating cellulosic biofuel renewable indemnification numbers (RINs) under the Renewable Fuel Standards (RFS), which can improve the economics of WTE projects.

Among available alternative fuel production technologies, biogas via $\mathrm{AD}$ and ethanol production via fermentation are regarded as suitable WTE pathways because they can avoid the energy-intensive drying pretreatment processes required for most thermochemical conversion methods. The AD process employs microorganisms to decompose organic matter, which produces biogas containing $50-70 \% \mathrm{CH}_{4}$ and $30-50 \% \mathrm{CO}_{2}$. The biogas can be further treated for pipeline-quality CNG or LNG. Ethanol can be produced by converting lignocellulosic biomass through enzymatic hydrolysis and fermentation processes, while the residuals are combusted to produce heat and power required for the conversion processes. Currently, $\mathrm{AD}$ is widely used for sludge from wastewater treatment, and there are huge research efforts focused on improving cellulosic ethanol production for various lignocellulosic feedstocks, such as corn stover, switchgrass, and poplar. The major challenge in applying these fuel conversion pathways for MSW is its non-homogeneous characteristics. Thus, appropriate separation processes are required for these WTE pathways.

Using waste for alternative fuel production pathways can avoid emissions and energy use required for current solid waste management practices that would otherwise be used. While the avoided emissions and energy use could be significant, it is still not clear whether the avoided emissions and energy use in the current management can be greater than those associated with the alternative fuel production pathways. In the landfill case, for example, uncontrolled $\mathrm{CH}_{4}$ emissions from landfills after flaring are released in current waste management. Due to the high global warming potential of $\mathrm{CH}_{4}$, avoiding these uncontrolled $\mathrm{CH}_{4}$ emissions is a major $\mathrm{GHG}$ 
emissions credit in the alternative WTE pathways, in addition to the credit from replacing conventional fuels with waste-derived fuels. On the other hand, a high fraction of carbon in waste is not decomposed and stays in landfills. This carbon would be released into the air as carbon emissions (mostly as $\mathrm{CO}_{2}$ ) if waste feedstock is used for energy recovery. Emissions from the carbon that would be sequestered in landfills are major GHG emissions in the alternative WTE pathways. Moreover, landfilling waste requires much less energy than WTE processes (such as $\mathrm{AD}$, fermentation, gasification, and hydrothermal liquefaction) do. Therefore, close examination is needed to show whether the alternative WTE pathways can result in net reductions in emissions and energy use relative to current waste management.

Lifecycle analysis (LCA) is widely used to analyze and compare environmental impacts of various energy conversion pathways. LCA of ground transportation fuels is commonly called a well-to-wheels (WTW) analysis because the analysis extends from feedstock recovery (well) to end use (wheels). WTW is divided into well-to-pump (WTP), which includes feedstock recovery, fuel production, transportation and distribution, and pump-to-wheels (PTW), which represents fuel combustion in a vehicle. This study compares the lifecycle GHG emissions and fossil fuel consumption for the alternative fuel production pathways using solid waste to the current solid waste management, using the Greenhouse Gases, Regulated Emissions, and Energy Use in Transportation (GREET ${ }^{\circledR}$ ) model developed by Argonne National Laboratory (Argonne 2015).

Because we assumed that the alternative fuel production pathways displace current waste management practices, only the relative changes in the two pathways would be considered. Therefore, it is critical to set up both the counterfactual scenarios representing current solid waste management and the alternative fuel production scenarios. In this study, landfilling waste with landfill gas (LFG) flaring is used as a counterfactual scenario because most non-recycled waste is landfilled, and the alternative fuel production scenario is likely to displace systems without energy recovery to maximize benefits. The parameters influencing the WTW results, such as LFG collection efficiencies, will be evaluated to demonstrate the relative impacts. 


\section{ANALYSIS APPROACH AND SYSTEM BOUNDARY}

\subsection{MARGINAL APPROACH}

As mentioned, US EPA approved renewable $\mathrm{CNG}, \mathrm{LNG}$, and electricity derived from biogas as well as hydrocarbon fuels generated from organic waste (such as yard trimmings, OFMSW, and separated food waste) for generating RINs under RFS. Note that these renewable fuels and electricity were originally approved as advanced biofuels $(>50 \% \mathrm{GHG}$ emission reduction) and later as cellulosic biofuels ( $>60 \%$ GHG emission reduction). However, current use scenarios (i.e., existing electricity generation from LFG) are not included for RINs to motivate first movers. In these approved pathways, EPA regards carbon in biogas and organic waste as carbon neutral. As an example, Figure 1a illustrates EPA's approach to LCA of renewable CNG, LNG, or electricity generated from biogas via AD of organic waste. The system boundary in EPA's approach starts from biogas. The energy and emissions associated with upstream processes (e.g., waste collection activities, recycling, and $\mathrm{AD}$ of waste) are not allocated to renewable CNG, LNG, and electricity.

This carbon neutrality assumption, however, may be questionable, especially for organic waste feedstock, because a fraction of carbon in organic waste can be sequestered in the soil for more than 100 years if landfilled. In order to see the net impact of diverting organic waste from the current management processes to the alternative WTE pathways, the lifecycle energy consumption and emissions from the current management, in addition to those in the alternative WTE pathways, need to be investigated and compared. To this end, this study uses a marginal approach, which assumes that an alternative fuel production scenario displaces a counterfactual scenario (i.e., current waste management) as illustrated in Figure 1b. In other words, if a dry ton of food waste is used to produce renewable CNG instead of being landfilled, it avoids the GHG emissions and energy use of landfilling a dry ton of food waste. Therefore, the marginal changes from the counterfactual scenario (or the net energy consumption and GHG emissions of the alternative scenario compared with the counterfactual scenario) are taken into account for the lifecycle energy and emissions calculation.

Because only the net energy and GHG emissions of the alternative WTE pathway compared with the counterfactual scenario are considered in the marginal analysis, the overlapping upstream processes, such as waste collection and transportation, are excluded, since they are present in both scenarios. Similarly, $\mathrm{CO}_{2}$ uptake credits by biomass growth are not included for the carbon in organic waste. As a result, this marginal approach does not differentiate the carbon in the waste by the source of the carbon (i.e., whether it is biogenic or fossil). 
a)

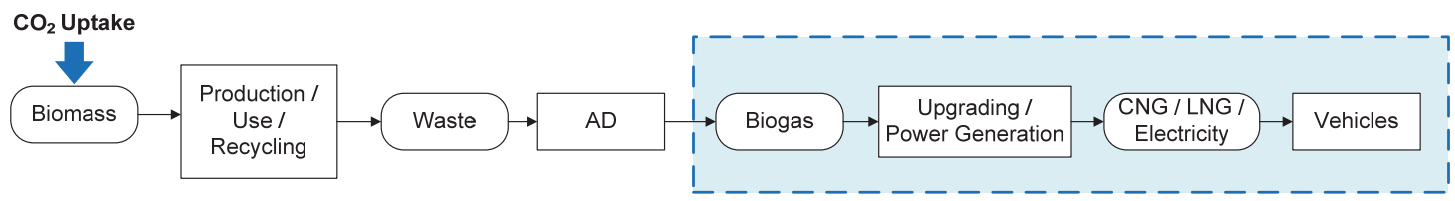

b)
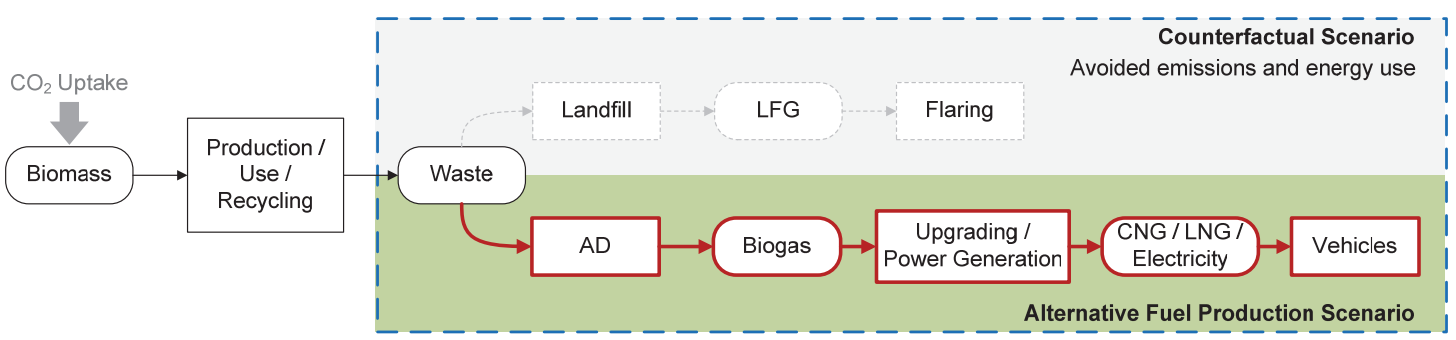

FIGURE 1 LCA Approach of WTE Pathways: a) EPA's Approach, and b) Marginal Approach

In the marginal approach, defining the counterfactual scenario is as critical as evaluating the alternative scenarios. Because this study focuses on utilizing waste materials to generate transportation fuels, the currently utilized waste is outside this analysis scope. US EPA reported that material recovery and combustion with energy recovery consumed $34 \%$ and $13 \%$ of total MSW generation, respectively, in 2013, and estimated that the remaining 53\% was landfilled (US EPA 2015). Based on EPA's solid waste management hierarchy, landfilling without energy recovery is the least preferred method (US EPA 2012), so landfilling non-recycled waste is selected as the counterfactual case of this study, and LFG collected at landfills is assumed to be flared, the current practice in many landfills. This portion of waste resources can benefit the most by being converted into fuels, and so is the most likely scenario to be displaced with the alternative fuel production scenarios.

\subsection{SYSTEM BOUNDARY}

Figure 2 shows the system boundary of the counterfactual scenario that landfills waste. Once the waste is landfilled, it starts generating $\mathrm{LFG}$, a mixture of $\mathrm{CH}_{4}$ and $\mathrm{CO}_{2}$, through organic waste decomposition processes by microbes. Generated LFG should be appropriately collected and combusted to reduce the global warming impact of methane, and it can be either flared or used to produce electricity. The uncaptured LFG would be released to the atmosphere, while a small portion of $\mathrm{CH}_{4}$ is oxidized to $\mathrm{CO}_{2}$. LFG generation varies by types of feedstock and climate conditions, and LFG collection efficiency largely depends on landfill operation. Note that not all carbon in waste is decomposed, and around half of the degradable carbon in waste stays in landfills, resulting in carbon sequestration. Because the counterfactual scenario directly influences the LCA results, we will evaluate key parameters in various conditions in detail. 


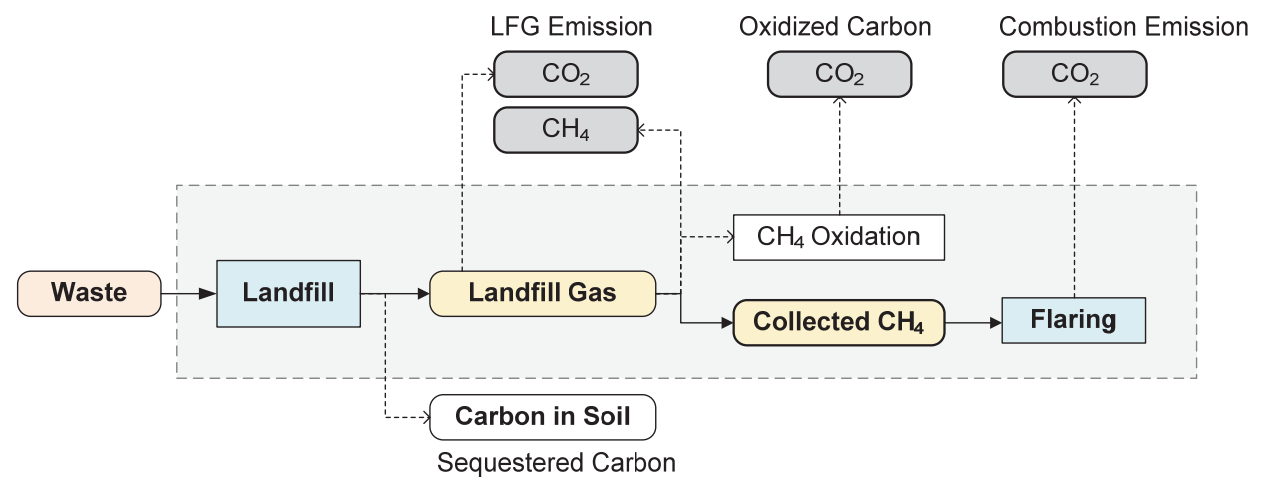

FIGURE 2 System Boundary of the Counterfactual Scenario (Landfilling Waste)

The system boundary of the two fuel production pathways using solid waste $-\mathrm{CNG}$ via $\mathrm{AD}$ and ethanol via fermentation - is shown in Figure 3. As shown in Figure 3a, AD processes produce biogas that can be further upgraded to CNG or LNG. The waste feedstock is fed to an anaerobic digester, which produces biogas containing $\mathrm{CH}_{4}$ and $\mathrm{CO}_{2}$. The biogas is then upgraded through multiple cleanup processes, scrubbing $\mathrm{CO}_{2}$ in order to produce pipeline-quality renewable natural gas (RNG). It can be compressed or liquefied to generate CNG or LNG, respectively, either on site or offsite at refueling stations.

The heat and electricity required for the $\mathrm{AD}$ processes and the system can be provided by combusting a portion of the biogas in a combined heat and power (CHP) system, and a boiler can be used if extra heat is needed. Note that a CHP requires more extensive cleanup processes for its feed gas than a boiler does. In this study, we assumed that the CHP is used only to meet onsite thermal and electric demands, while the rest of the RNG is used to generate CNG.

Digestate, a solid residue, is produced during the $\mathrm{AD}$ process along with the biogas. $\mathrm{EPA}$ classifies digestate into Class A and Class B biosolids according to the level of pathogens. While EPA Class B needs to be disposed of in landfills, EPA Class A biosolids are considered a fertilizer replacement due to their low pathogen levels. Therefore, when Class A biosolids are generated, fertilizer credits can be earned based on the amount of the GHG emissions and energy use associated with commercial fertilizer production and transportation.

The major emission sources of the AD processes are combustion emissions from the CHP and fuel combustion emissions from vehicles, and non-combustion emissions that mainly consist of $\mathrm{CH}_{4}$ and $\mathrm{CO}_{2}$. Non-combustion $\mathrm{CH}_{4}$ emissions are mainly leakages from the $\mathrm{AD}$ systems and emissions from digestate decomposition, and non-combustion $\mathrm{CO}_{2}$ emission sources include the $\mathrm{CO}_{2}$ in biogas from $\mathrm{AD}$ released during the cleanup processes and the decomposition of digestate. The amount of $\mathrm{CO}_{2}$ emissions from digestate decomposition can be estimated from the balance of the carbon in the digestate applied to soil and the sequestered carbon in the soil.

Figure $3 \mathrm{~b}$ shows the system boundary of ethanol production via fermentation. This study assumes that this ethanol production pathway uses lignocellulosic waste feedstocks. The system generates ethanol through fermentation processes using heat and power supported from biogas 
and biomass combustion. If there is excess electricity after meeting the onsite demand, it is exported to the grid. Because the fermentation processes require chemicals and fossil fuels such as natural gas and diesel fuel, upstream energy use and GHG emissions related to the chemical and fossil fuel production and transportation are included in the analysis. Carbon in the waste is eventually released into the atmosphere because, unlike the AD processes, this process does not have residuals that sequester carbon. The major emissions sources are combustion emissions in a boiler and a vehicle, and non-combustion emissions during the fermentation processes.

a)

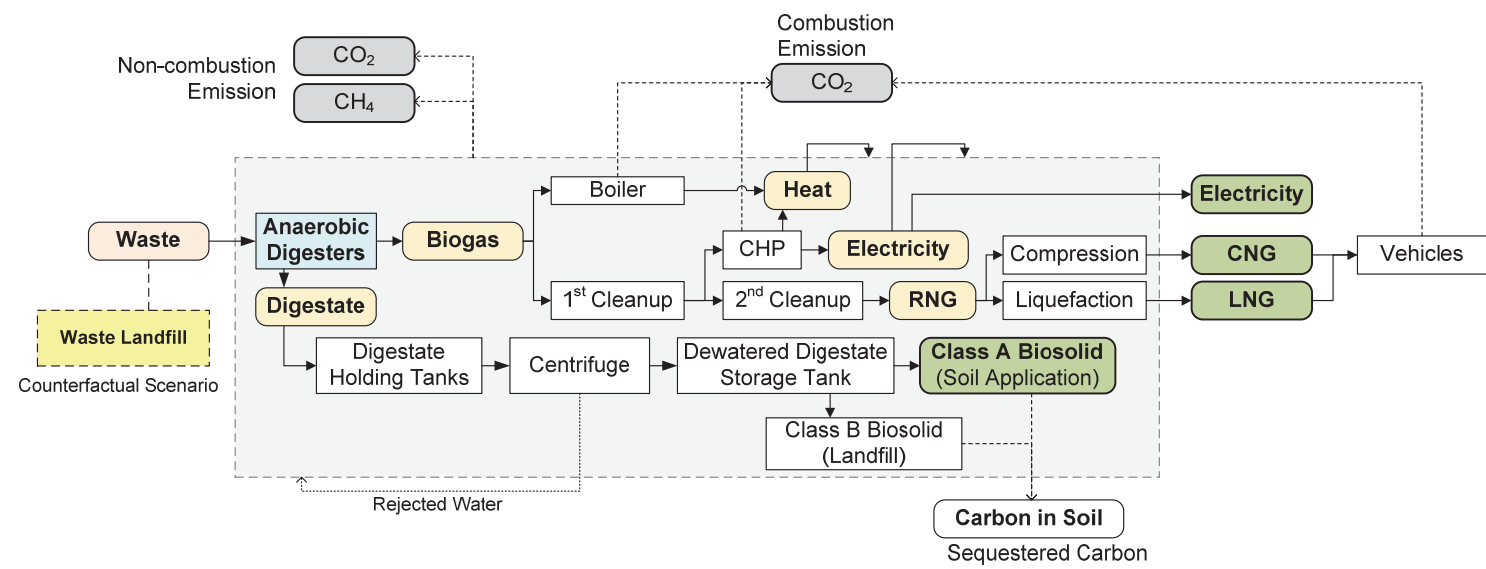

b)

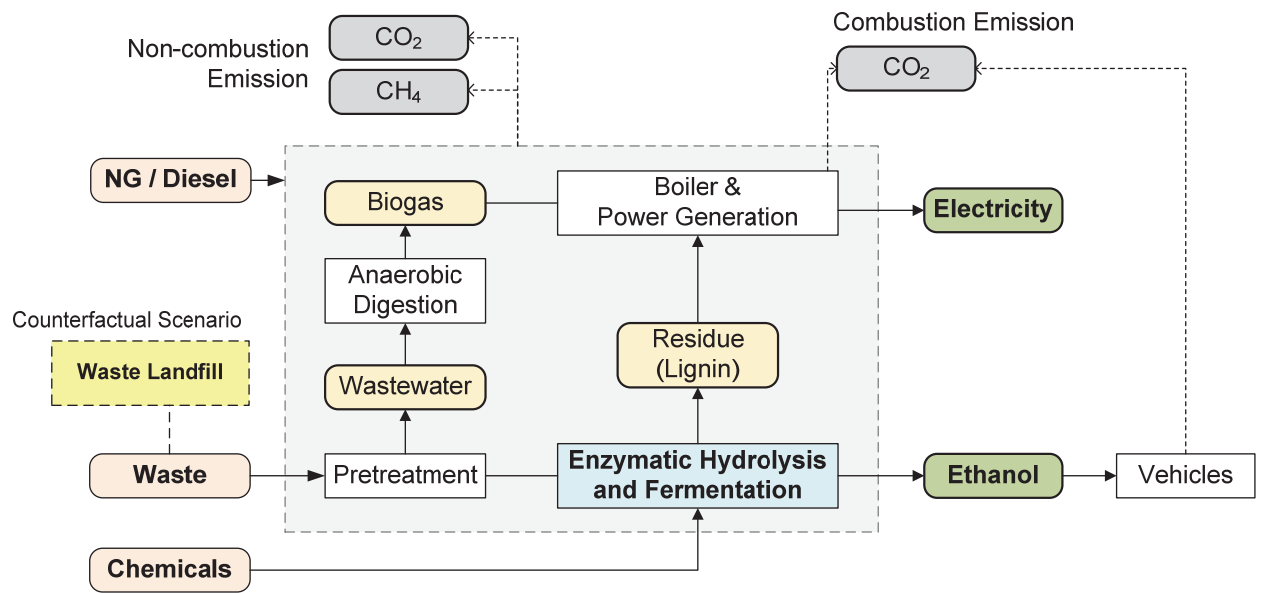

FIGURE 3 System Boundary of the WTE Pathways: a) CNG and LNG Production via Anaerobic Digestion and b) Ethanol Production via Fermentation 


\section{PARAMETRIC ASSUMPTIONS}

\subsection{FEEDSTOCK CHARACTERIZATION}

The typical composition of landfilled MSW in the United States is shown in Table 1 (US EPA 2015). It shows that five organic waste materials - paper, textiles, food, wood, and yard trimmings - constitute around $60 \%$ of total MSW by weight. Because inorganic materials such as glass and metals cannot be used for fuel production, only organic waste materials can be considered as possible feedstocks for the alternative scenarios.

Because fuel production processes are sensitive to types and conditions of feedstocks, the WTE pathways we are considering use specific organic feedstocks that are suitable for their conversion processes. In this study, source-separated food waste and yard trimmings are used for the $\mathrm{AD}$ and fermentation processes, respectively.

\section{TABLE 1 Discarded Solid Waste Composition in} the United States in 2013 (US EPA 2015)

\begin{tabular}{lr}
\hline \multicolumn{1}{c}{ Material } & $\begin{array}{c}\text { Composition } \\
\text { (wt. \%) }\end{array}$ \\
\hline Paper & \\
Glass & $15.1 \%$ \\
Ferrous & $5.0 \%$ \\
Aluminum & $7.0 \%$ \\
Other nonferrous metals & $1.7 \%$ \\
Plastics & $0.4 \%$ \\
Rubber and leather & $17.7 \%$ \\
Textiles & $3.9 \%$ \\
Wood & $7.7 \%$ \\
Other materials & $8.0 \%$ \\
Food & $2.0 \%$ \\
Yard trimmings & $21.1 \%$ \\
Miscellaneous inorganic wastes & $8.1 \%$ \\
\hline
\end{tabular}

\subsection{COUNTERFACTUAL SCENARIO: WASTE LANDFILL}

For marginal analyses, evaluating the counterfactual scenarios is as important as evaluating the alternative scenarios. In this section, GHG emissions from landfilled waste are evaluated for use as the counterfactual case. Once organic waste is disposed of in landfills, it starts generating $\mathrm{LFG}$, mainly $\mathrm{CH}_{4}$ and $\mathrm{CO}_{2}$, through $\mathrm{AD}$, and landfill operators collect the generated LFG as required by regulations. The LFG collection process captures and flares $\mathrm{CH}_{4}$ 
to reduce global warming impact by releasing $\mathrm{CO}_{2}$ instead of $\mathrm{CH}_{4} . \mathrm{CH}_{4}$ also can be used to generate electricity, depending on economic feasibility. Not all LFG generated in landfills can be collected, and uncontrolled LFG, a portion of the uncollected LFG, is emitted to the atmosphere. A small amount of $\mathrm{CH}_{4}$ in the uncontrolled LFG is oxidized into $\mathrm{CO}_{2}$ as the LFG passes through landfill covers.

Measuring $\mathrm{CH}_{4}$ emissions is not easy, because landfills are large, and landfilled organic waste takes several decades to be completely decomposed. Thus, $\mathrm{CH}_{4}$ emissions, $\mathrm{CH}_{4}$,emission, are typically estimated through the relationship expressed in Equation 1 below,

$$
\mathrm{CH}_{4, \text { emission }}=\mathrm{CH}_{4, \text { generation }}-\mathrm{CH}_{4, \text { collected }}-\mathrm{CH}_{4, \text { oxidized }} \quad \text { Equation } 1
$$

where $\mathrm{CH}_{4}$,generation, $\mathrm{CH}_{4}$,collected, and $\mathrm{CH}_{4}$,oxidized indicate the amount of $\mathrm{CH}_{4}$ generated, collected and combusted, and oxidized into $\mathrm{CO}_{2}$, respectively. They must be estimated properly to calculate $\mathrm{CH}_{4}$ emissions from landfills.

On the other hand, all generated $\mathrm{CO}_{2}$ in $\mathrm{LFG}$ is either collected and vented or uncollected and released through LFG soil. Thus, the total amount of non-combustion $\mathrm{CO}_{2}$ emissions from the $\mathrm{CO}_{2}$ generated in LFG is unaffected by LFG collection and flaring. In addition, $\mathrm{CO}_{2}$ from $\mathrm{CH}_{4}$ oxidation is added to non-combustion $\mathrm{CO}_{2}$ emissions from landfills. Therefore, the total amount of non-combustion $\mathrm{CO}_{2}$ emissions is estimated as the sum of the amount of $\mathrm{CO}_{2}$ generated in $\mathrm{LFG}$ and the $\mathrm{CO}_{2}$ from $\mathrm{CH}_{4}$ oxidation.

\subsection{1 $\mathrm{CH}_{4}$ Generation}

$\mathrm{CH}_{4}$ generation from organic materials depends on various parameters such as types of waste, moisture content, and site-specific climate conditions like temperature and precipitation. A first-order decay (FOD) model is typically used to estimate LFG generation. The model assumes that organic decomposition follows the first order decay characteristics, and the parameters on the types of feedstocks and the climate conditions obtained from the actual data sets are plugged into the fitted $\mathrm{CH}_{4}$ generation curves. The Intergovernmental Panel on Climate Change (IPCC) suggests using the FOD model for the GHG inventory of $\mathrm{CH}_{4}$ generated from landfills, and 40 Code of Federal Regulations (CFR) Part 98 requires landfill operators to report GHG emissions using this method in the United States (40 CFR Part 98; IPCC 2006).

The equation calculating annual $\mathrm{CH}_{4}$ generation, $G_{\mathrm{CH}_{4}}$, specified in the code of federal regulations (40 CFR Part 98, Subpart HH 2016) is shown in Equation 2. $W_{x}$ represents the wet weight of discarded waste. Possible carbon emissions are then calculated by applying three parameters - degradable organic carbon $(D O C)$, the fraction of DOC that decomposes $\left(D O C_{F}\right)$, and methane correction factor $(M C F)$. The $D O C$ expresses the amount of degradable carbon contained in the feedstock, and it depends entirely on the types of the waste. Because not all degradable carbon decomposes, $D O C_{F}$ values are used to estimate the amount of carbon that does decompose. IPCC suggests using 0.5 , which means $50 \%$ of the degradable carbon in landfilled waste would be eventually released to the atmosphere, and the rest of the carbon remains in landfills. The $M C F$ is used to adjust anaerobic and aerobic conditions, because $\mathrm{CH}_{4}$ is 
easily oxidized into $\mathrm{CO}_{2}$ at aerobic conditions. It depends on disposal site conditions, which vary from 1.0 for managed anaerobic digestion to 0.4 for unmanaged shallow waste.

Multiplying these parameters $\left(W_{x}, D O C, D O C_{F}\right.$, and $\left.M C F\right)$ calculates the total amount of carbon emission generated. Once the amount of generated carbon emission is calculated, it can be used to estimate total generated $\mathrm{CH}_{4}$ emission, given the concentration of $\mathrm{CH}_{4}$ in $\mathrm{LFG}(F)$ and the molecular ratio of $\mathrm{CH}_{4}$ to $\mathrm{C}(16 / 12)$. Similarly, non-combustion $\mathrm{CO}_{2}$ emissions can be estimated from the amount of generated carbon emissions by multiplying the concentration of $\mathrm{CO}_{2}$ in $\mathrm{LFG}(1-F)$ by the molecular ratio of $\mathrm{CO}_{2}$ to $\mathrm{C}(44 / 12)$.

Decomposition speed varies depending on the climate and feedstock conditions, and a reaction constant, $k$, represents the speed of decay. IPCC specifies $k$ values for MSW components under four different climate conditions, as shown in Table 2, based on measurements from the field. $S$ and $T$ stand for the year of start and time of reporting, respectively, while $x$ represents the year in which the waste was disposed of.

Using Equation 2, the annual $\mathrm{CH}_{4}$ generation can be calculated over time. In this analysis, $D O C_{F}, M C F$, and $F$ are set at $0.5,1.0$ and 0.5 by default, while other parameters are selected considering the types of feedstock and climate conditions in Table 2.

$$
G_{C H_{4}}=\sum_{x=S}^{T-1}\left[W_{x} \times D O C \times D O C_{F} \times M C F \times F \times \frac{16}{12} \times\left\{e^{-k(T-x-1)}-e^{-k(T-x)}\right\}\right] \quad \text { Equation } 2
$$

TABLE 2 Degradable Organic Carbon (DOC) and Reaction Constant (k) (IPCC 2006)

\begin{tabular}{|c|c|c|c|c|c|c|}
\hline & \multirow[b]{2}{*}{$\begin{array}{c}D O C \\
\text { (in \% of wet waste) }\end{array}$} & \multirow[b]{2}{*}{$\begin{array}{l}\text { Moisture } \\
\text { Content }\end{array}$} & \multicolumn{4}{|c|}{$k$} \\
\hline & & & $\begin{array}{c}\text { Boreal } \\
\text { / Dry }\end{array}$ & $\begin{array}{l}\text { Boreal } \\
\text { / Wet }\end{array}$ & $\begin{array}{c}\text { Tropical } \\
\text { / Dry }\end{array}$ & $\begin{array}{c}\text { Tropical } \\
\text { / Wet }\end{array}$ \\
\hline Paper & 0.41 & $6 \%$ & 0.04 & 0.06 & 0.045 & 0.07 \\
\hline Textiles & 0.30 & $10 \%$ & 0.04 & 0.06 & 0.045 & 0.07 \\
\hline Wood & 0.43 & $20 \%$ & 0.02 & 0.03 & 0.025 & 0.035 \\
\hline Food & 0.14 & $72 \%$ & 0.06 & 0.185 & 0.085 & 0.4 \\
\hline Yard Trimmings & 0.20 & $60 \%$ & 0.05 & 0.1 & 0.065 & 0.17 \\
\hline
\end{tabular}

\subsection{2 $\mathrm{CH}_{4}$ Collection and Oxidation}

The amount of collected $\mathrm{CH}_{4}, \mathrm{CH}_{4}$,collected, can be calculated by multiplying a collection efficiency to the estimated $\mathrm{CH}_{4}$ generation. The collection efficiency is defined as the amount of $\mathrm{CH}_{4}$ collected over the amount of total $\mathrm{CH}_{4}$ generation. US EPA uses a fixed collection efficiency of $75 \%$ for sanitary landfills under New Source Performance Standards (NSPS). The California Department of Resources Recycling and Recovery (CalRecycle) and California Air 
Resources Board (ARB) evaluated lifetime LFG collection efficiency (ARB 2016). Instead of using constant $75 \%$ collection efficiency, they divided landfill operation into three phases for a better estimate, which leads $70 \%$ of lifetime collection efficiency. However, there are many parameters that influence collection efficiency, such as the type of collector used, landfill cover conditions, and landfill operation, so it is important to figure out major parameters affecting collection efficiency over its lifetime. Landfill operators usually design and operate landfills by "cell," an operation unit developed to minimize operating surface area, and the concept of collection phases should be applied to the cells rather than the entire landfill. Depending on the cell capacity and waste acceptance rate, cell lifetime typically varies from two to ten years, and landfills consist of up to around a dozen cells. Because LFG collection plans follow cell development, a cell is used for the simulation to reflect the actual practices in this analysis.

There are three main types of landfill covers — daily, intermediate, and final — based on materials, thickness, and application period of the covers. Landfill covers influence collection efficiency because of the different $\mathrm{CH}_{4}$ permeability and oxidation rates of the different cover types. Covers also influence the pressure in waste landfills, which affects the operating conditions of the collectors. A daily cover is six inches of soil or alternative materials applied at the end of each day, mainly to control odors, blowing litter, and fire. If there is no plan to dispose of waste within 180 days, an intermediate (temporary) cover, which is 18 inches of soil or the equivalent, is applied to reduce infiltration of rainfall and fugitive $\mathrm{CH}_{4}$ emissions as well as odors, blowing litter, and fire. Final covers consisting of multiple low-permeability layers are installed to manage landfills in the long term and are intended to control LFG and leachate. The timing of final cover installation varies depending on the designed landfill cell operation. As long as the operation meets the regulations, a cell may be capped with final covers when the cell is closed, or several cells may be covered at the same time to minimize costs.

Two types of collectors are commonly used for LFG collection - horizontal collectors and vertical collectors. Horizontal collectors can be installed while cells accept waste. They are intended to collect LFG in the early stage of the cell's development. As soon as 20-40 feet of waste is in place over the collectors, enough vacuum is built to operate horizontal gas collectors. It may start as early as three months after the first waste disposal for a cell with a high waste disposal rate. However, horizontal collectors are typically operational only for around three to four years and cannot be used for a long period due to the possibility of flooding. Vertical collectors, on the other hand, can be installed after final covers have been installed, and so they cannot collect LFG in the early cell development period. The vertical collectors typically have a high collection efficiency because they are under high vacuum conditions with the help of the final covers and a large amount of surrounding waste. The vertical collectors are less prone to flooding than the horizontal gas collectors, which makes them a better long-term collection method.

LFG collection efficiency mainly depends on the landfill covers and the collector conditions, and the operation of LFG collection can be seen as having three major phases in a typical landfill operation. First, LFG collection efficiency is low while cells accept waste, because the cells are mostly covered with highly permeable daily covers, and the horizontal collectors cannot build vacuum efficiently (Phase I). Once the cell is closed and temporary covers are applied, relatively higher collection efficiency can be obtained (Phase II) compared 
with Phase I. Finally, installing final covers and operating vertical gas collectors lead to the highest collection efficiency (Phase III). The collection efficiency of Phase III has been thoroughly studied (Barlaz, Chanton, and Green 2009; Spokas et al. 2006), while that of Phase I and Phase II have not been well evaluated, because all landfill operations in these phases are different from one another. Therefore, estimations by experts are used for these two phases. Table 3 summarizes the collection efficiency of each phase estimated by three independent organizations. SCS Engineers (2008) estimated moderate collection efficiencies for Phase I, Phase II, and Phase III as 60\%, 75\%, and 95\%, respectively. Barlaz et al. (2009) estimate the collection efficiency of Phase I to be slightly lower (50\%) than SCS Engineers, while the rest are the same. The French environmental agency (ADEME) sets the lowest collection efficiencies for regulation purposes and conservatively estimates the LFG collection, resulting in the highest LFG emissions. It can be found that the collection efficiencies of Phase II and Phase III are within a narrow range, while estimations for Phase I vary due to a various cell operating conditions. In this study, the values of Barlaz et al. (2009) are used to represent the collection efficiencies of the United States, because LFG emissions during Phase I are estimated more conservatively than those of SCS Engineers.

TABLE 3 Collection Efficiency by Landfill Operation Phase

\begin{tabular}{lcccl}
\hline & Phase I & Phase II & Phase III & \multicolumn{1}{c}{ References } \\
\hline & & & & \\
SCS Engineers & $60 \%$ & $75 \%$ & $95 \%$ & (SCS Engineers 2008) \\
Barlaz et al. & $50 \%$ & $75 \%$ & $95 \%$ & (Barlaz et al. 2009) \\
French (ADEME) & $35 \%$ & $65 \%$ & $90 \%$ & (Spokas et al. 2006) \\
\hline
\end{tabular}

Phase I: Active cells

Phase II: Closed cells with temporary covers

Phase III: Closed cells with final covers

Landfill operators are required to maintain post-closure care for 30 years, and both active and closed landfills have the same LFG control requirements. Because there is no economic benefit to operating the collectors after the post-closure care period, due to low LFG generation, we assume that landfills would not collect LFG at this period unless the emissions from the landfill exceed the regulation criteria.

In order to simulate the LFG collection over the landfill's lifetime, we conducted interviews to understand actual landfill operation in two landfills representing active and moderate LFG collection. A large landfill located in Illinois, with a capacity of 70 million tons and a disposal rate of 1.5 million tons per year, represents active LFG collection, because LFG is collected from the early stage. The landfill has 20 cells with a capacity of 3.5 million tons each. A medium-sized landfill, also located in Illinois, with a capacity of 24 million tons and a disposal rate of 0.3 million tons per year, has been selected to represent landfills with moderate LFG collection. The landfill starts collecting LFG right before the cells' closure to meet regulations, rather than from the beginning of the cell operation. The landfill has 12 cells with a capacity of 
2 million tons each. The interviews showed that large landfills tend to actively collect LFG, mainly to control odor and meet emissions regulations. Figure 4 shows LFG collection and cover installation plans for a landfill cell, obtained through the interview, which we used for the simulation cases representing active and moderate LFG collection cases.

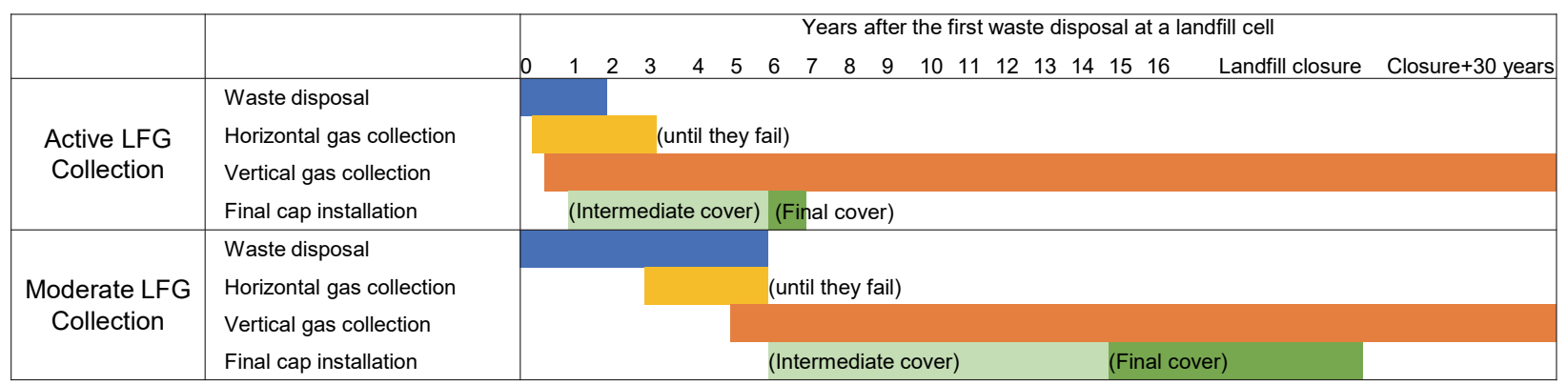

FIGURE 4 LFG Collection and Cover Installation Plans of a Landfill Cell for Active and Moderate LFG Collection Cases

When non-captured $\mathrm{CH}_{4}$ goes through the soil covers, $\mathrm{CH}_{4}$ is partially oxidized into $\mathrm{CO}_{2}$. Though the amount of $\mathrm{CH}_{4}$ oxidation, $\mathrm{CH}_{4}$,oxidized, is influenced by many parameters, such as the amount of $\mathrm{CH}_{4}$ passing through the soil, porosity of the soil covers, and temperature and water content profiles, oxidation is commonly estimated as $10 \%$ of non-collected $\mathrm{CH}_{4}$. When sitespecific oxidation data are available, the actual value may be used instead.

\subsubsection{Lifetime $\mathrm{CH}_{4}$ Generation, Collection, and Emissions Profiles and LFG Collection Efficiencies}

Figure 5 shows simulation results using information from the two different landfills above and based on the assumption that one dry ton of yard trimmings waste per year is landfilled in boreal and wet conditions. In order to compare the collection efficiencies, the number of cells has been adjusted to have the same 36-year landfill lifetime. The simulated landfills collect LFG for 30 years after the landfill closure as required by regulation, and after that it is released into the atmosphere without collection. A first-order decay model is used to simulate $\mathrm{CH}_{4}$ generation, and the set of collection efficiencies of Barlaz et al. (2009) in Table 3 is used by default. The results show that $\mathrm{CH}_{4}$ collection varies a lot over time depending on landfill operation. In the moderate LFG collection case, LFG cannot be captured at the early stage of each cell due to delayed collector installation. It results in relatively lower collection efficiency compared with the active LFG collection case. The lifetime collection efficiencies of the active and moderate LFG collection cases are $83 \%$ and $69 \%$, respectively, for yard trimmings waste. The active case collects $21 \mathrm{~kg} \mathrm{CH}_{4}$ more per dry ton of landfilled yard trimmings waste than the moderate case. For food waste, the lifetime collection efficiencies of the active and moderate LFG collection cases are $79 \%$ and $59 \%$, respectively. Food waste has lower collection efficiencies than yard trimmings under the same landfill operating conditions because of its rapid decomposition rate, resulting in more losses of LFG before collection starts. 


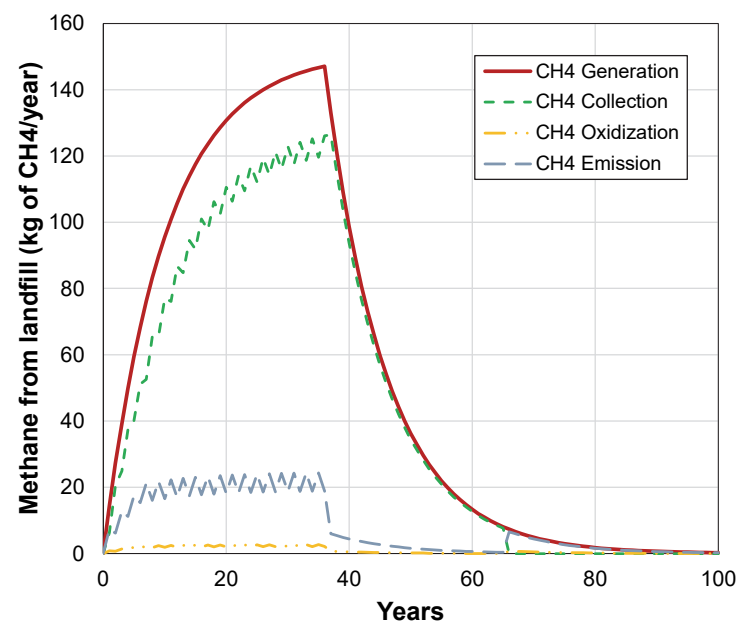

a) Active LFG Collection

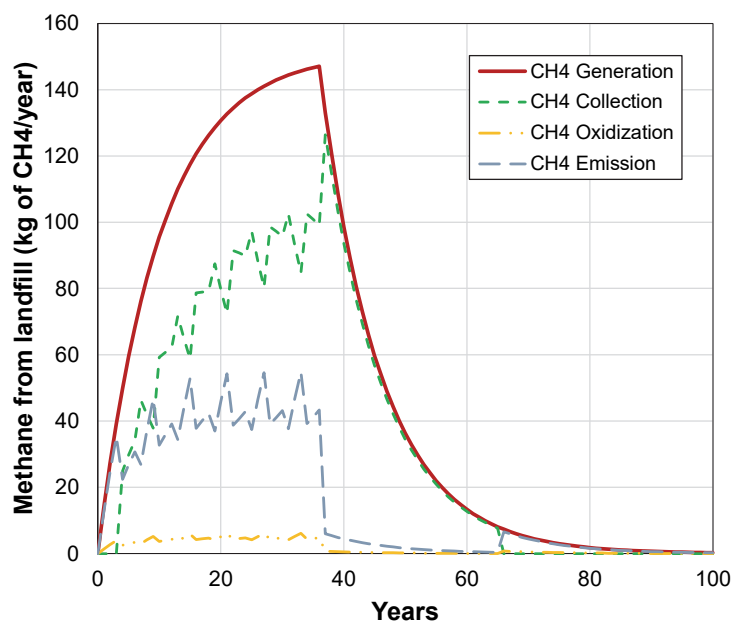

b) Moderate LFG Collection

FIGURE 5 Simulation Results of Methane Generation, Collection, Oxidization, and Emission from Waste Landfills with a) Active LFG Collection and b) Moderate LFG Collection (Both for Yard Trimmings Waste)

\subsection{ALTERNATIVE FUEL PRODUCTION}

\subsubsection{CNG Production Using Anaerobic Digestion}

Banks et al. (2011) monitored a full-scale anaerobic digester that received sourcesegregated food waste over a 14-month period and performed comprehensive mass and energy balance based on the measured data. During this time, the anaerobic digester processed 3,936 wet MT of food waste and generated $275 \mathrm{MT}_{\text {of }} \mathrm{CH}_{4}$, equivalent to $13,041 \mathrm{mmBtu}$. The feedstock used was mostly from source-separated domestic food waste $(95.5 \%)$ plus a small amount of food waste from restaurants and local businesses. Food waste was shredded to reduce the size, mixed with digestate, and macerated. It then headed to an anaerobic digester, a $900 \mathrm{~m}^{3}$ tank maintained at $42^{\circ} \mathrm{C}$. Biogas containing $\mathrm{CH}_{4}$ and $\mathrm{CO}_{2}$ is generated through the $\mathrm{AD}$ process.

Table 4 shows the $\mathrm{CH}_{4}$ yield along with $\mathrm{CO}_{2}$ emissions for a dry ton of food waste input (the moisture content of food waste input is $72 \%$ ). The analysis shows that biogas consists of $63 \%$ of $\mathrm{CH}_{4}$ and $37 \%$ of $\mathrm{CO}_{2}$ by volume. The amount of digestate in Table 4 has been calculated using a mass balance. 
TABLE 4 Key Products, Emissions and Energy Requirements of the AD Process Using Food Waste (Banks et al. 2011)

\begin{tabular}{lc}
\hline \multicolumn{1}{c}{ Key Products and Requirements } & Value \\
\hline & \\
Products and Emissions (kg/dry ton of waste) & 226 \\
$\mathrm{CH}_{4}$ yield & 299 \\
Digestate & 371 \\
$\mathrm{CO}_{2}$ emission during the AD process & \\
& \\
Heat and Power Requirements (mmBtu/dry ton of waste) & 1.25 \\
Heat requirement & 0.76 \\
Electricity requirement
\end{tabular}

The AD system uses the biogas produced to generate electricity using CHP, and detailed information is available in the previous report (Lee et al. 2016). That electricity meets the onsite power demand, and the excess is exported to the grid. Banks et al. (2011) calculated the electricity requirements by subtracting the exported electricity from the power generation in the $\mathrm{CHP}$ and found that the primary electricity consumers are fans, gas mixing equipment, compressors, and the waste shredder. Thermal requirements to maintain the anaerobic digester and pasteurizer temperature have been calculated using feedstock input volumes, tank dimensions, and heat transfer coefficients. The thermal requirements may vary by region, mainly because of the different ambient temperature. Because the case has been evaluated at Lyonshall in the UK, which has an annual average temperature of $9^{\circ} \mathrm{C}$, it is expected that the thermal requirements would be comparable for the anaerobic digesters located in Chicago or New York, where the annual average temperatures are similar.

While in the example above all of the biogas was combusted to generate electricity, this study assumes that only a minimal amount of biogas is used to support onsite heat and power requirements. The remaining biogas is upgraded to pipeline-quality natural gas, which is then further compressed to CNG or liquefied to LNG. Because the paper by Banks et al. (2011) does not include biogas upgrading processes and fugitive emissions coming from various $\mathrm{AD}$ stages, we have incorporated additional resources into the following discussion.

Fugitive $\mathrm{CH}_{4}$ emission is one of the key parameters which influence overall GHG emissions, due to its high global warming potential. It is emitted from biogas production, upgrading, and digestate treatment processes, and it is even released from the digestate applied to soil or disposed of in landfills. Argonne previously performed comprehensive research on biogas upgrading processes generated from landfill gas, manure-based biogas, and sludge-based biogas (Han, Mintz, and Wang 2011; Mintz et al. 2010; Lee et al. 2016). Thus, the assumptions used here for fugitive $\mathrm{CH}_{4}$ emission at each production stage and from biogas upgrading are applied to the biogas generated from solid waste. Detailed information is available from the report by Lee et al. (2016). 
As mentioned, digestate can be classified as EPA Class A or Class B biosolids depending on the quality of the digestate. Class A biosolids can be used as fertilizer, while Class B biosolids must be landfilled due to their level of pathogens. In the anaerobic digester studied, the generated digestate was heated to $70^{\circ} \mathrm{C}$ for at least one hour to pasteurize it, using heat supported by a CHP unit (Banks et al. 2011), which is expected to meet the EPA's Class A biosolids criteria. The dewatered digestate becomes a fertilizer that avoids the GHG emissions and energy consumption required for producing and transporting the same amount of conventional chemical fertilizers. It is assumed that the nutrients in the digestate (nitrogen $[\mathrm{N}]$, phosphorus $[\mathrm{P}]$, and potassium $[\mathrm{K}]$ ) displace conventional fertilizers by mass. The measured average $\mathrm{N}, \mathrm{P}$, and $\mathrm{K}$ in digestate are 5.6, 0.4 , and $2.3 \mathrm{~kg}$ per wet MT of food waste, respectively (Banks et al. 2011). Carbon in digestate can be either sequestered in the soil or released into the atmosphere. In this study, once the digestate is applied to soil, $20 \%$ of the degradable carbon in digestate is considered sequestered under aerobic conditions. This carbon sequestration is later used to calculate non-combustion $\mathrm{CO}_{2}$ emissions.

Co-locating WTE projects with landfills has several advantages. For example, the WTE projects can use the existing landfill infrastructure, lowering the capital investment needed, while the landfill can maintain the amount of waste it receives, which is an important source of its revenue. Therefore, the energy consumption and emissions for transporting waste to the facilities are the same in the counterfactual scenario and the alternative scenario and have not been considered in this analysis. We assumed that the digestate would be transported to its final application, located 40 miles from the anaerobic digesters, and the RNG produced is assumed to be transported via pipelines to a fueling station 50 miles away, where it is compressed to CNG. These assumptions for transportation, distribution, and RNG compression are the same as in the previous studies (Han, Mintz, and Wang 2011; Mintz et al. 2010; Lee et al. 2016).

\subsubsection{Ethanol Production Using Fermentation}

The National Renewable Energy Laboratory (NREL) developed a detailed process design for techno-economic analysis of ethanol production via enzymatic hydrolysis and fermentation processes using its Aspen model and using corn stover as the feedstock (Humbird, et al. 2011). Corn stover is the most abundant agricultural residue and is typical lignocellulosic biomass. The designed plant is assumed to handle 882,000 dry tons per year.

First, the feedstock is pretreated with dilute sulfuric acid catalyst in a high-temperature environment to produce homogeneous particle size distribution, moisture content, and bulk density. It is then mixed with ammonia to prepare it for enzymatic hydrolysis and sent to a continuous reactor where the hydrolyzed slurry is processed and inoculated with the microorganism. This fermentation process produces ethanol. Residual solids from the fermentation stage are combusted along with the biogas generated from AD of the wastewater from the pretreatment stage. Heat and power generated during the combustion process are used to support the onsite demands. If there is excess electricity, it is exported to the grid. The system needs chemicals for the fermentation process, such as sulfuric acid and ammonia, and the upstream GHG emissions and fossil fuel consumption to provide these chemicals are considered 
in the analysis. The chemicals and fuel required for the ethanol production processes are shown in Table 5.

TABLE 5 Input Chemical Loading and Products

\begin{tabular}{lc}
\hline \multicolumn{1}{c}{ Inputs and Products } & (per dry ton feedstock) \\
\hline & \\
Energy Use & \\
Diesel fuel & $0.026 \mathrm{mmBtu}$ \\
Natural gas & $0.256 \mathrm{mmBtu}$ \\
& \\
Input Chemicals & \\
Sulfuric acid $\left(\mathrm{H}_{2} \mathrm{SO}_{4}\right)$ & $29 \mathrm{~kg}$ \\
Ammonia $\left(\mathrm{NH}_{3}\right)$ & $3.5 \mathrm{~kg}$ \\
Corn steep liquor & $11.2 \mathrm{~kg}$ \\
Diammonium phosphate (DAP) & $1.2 \mathrm{~kg}$ \\
NaOH & $10.0 \mathrm{~kg}$ \\
CaO & $6.5 \mathrm{~kg}$ \\
Urea & $1.8 \mathrm{~kg}$ \\
& \\
Products & \\
Ethanol & $79 \mathrm{gal}$ \\
Excess electricity & $142 \mathrm{kWh}$ \\
\hline
\end{tabular}

As shown in Table 5, the ethanol yield from corn stover in the NREL's study is $79 \mathrm{gal} / \mathrm{dry}$ ton of feedstock, and the excess electricity generated is $1.8 \mathrm{kWh} / \mathrm{gal}$ of ethanol output, which is equivalent to $142 \mathrm{kWh} /$ dry ton feedstock input. Note that the electricity use at the plant is estimated at $3.9 \mathrm{kWh} / \mathrm{gal}$, equivalent to $308 \mathrm{kWh} /$ dry ton feedstock. In order to evaluate ethanol produced from specific feedstock at certain conditions, detailed information on ethanol yields and electricity generation are needed. Also, there might be additional pretreatment processes, depending on waste feedstock conditions, to make it suitable for fermentation processes. However, due to insufficient information, we assumed that all lignocellulosic biomass-derived waste, such as yard trimmings, wood waste, and paper, has an ethanol yield identical to that of the corn stover in the design case on a dry ton of feedstock input basis, since the characteristics (e.g., carbon content, heating values, etc.) of these waste feedstocks are similar to corn stover on a dry ton basis. Net electricity generation, however, can be adjusted to compensate for the differences in energy required to vaporize the moisture in the input feedstocks. The moisture content of the corn stover in the NREL's design case is $20 \%$.

When other types of waste feedstocks are used instead, the differences in moisture content result in different energy requirements. For example, when yard trimmings waste, with a moisture content of $60 \%$, is used, the feedstock has six times more moisture per dry ton of feedstock, or an additional 1.25 ton of moisture per dry ton of feedstock treated than the design 
case. Given the enthalpy of water vaporization, 2,139 Btu/ $/ \mathrm{kg} \mathrm{H}_{2} \mathrm{O}$, extra moisture in yard trimmings consumes $2.4 \mathrm{mmBtu} /$ dry ton feedstock. With a power generation efficiency of $25 \%$, this additional moisture content reduces power generation by $178 \mathrm{kWh} /$ dry ton feedstock, resulting in net electricity generation of $-36 \mathrm{kWh} /$ dry ton feedstock. However, because drying is commonly done by steam, we assumed that natural gas would be imported to meet energy requirements when net electricity generation becomes negative. For yard trimmings waste, an additional $0.61 \mathrm{mmBtu} /$ dry ton of natural gas would be required, assuming $80 \%$ boiler efficiency.

In LCA, co-produced electricity can be treated using either a displacement method or an energy allocation method. In this study, the displacement method is used by default. If there is excess electricity, it earns credits for exported electricity, assuming that it displaces local electricity, and the main product, ethanol, takes all energy and emissions burdens during the process. The energy allocation method also can be used, which allocates the emissions and energy consumption by the energy share of the produced ethanol among total energy products.

It should be noted that the NREL's design case assumes handling a huge amount of lignocellulosic feedstock. In order to match the amount of input feedstock of the design case, 18 large landfills with a waste acceptance rate of 1.5 million wet tons per year, or 91 medium landfills with a waste acceptance rate of 0.3 million wet tons per year, are needed. Considering per capita MSW generation (e.g., 0.80 tons/person/year) and the yard trimmings share of that (US EPA 2015), the design case requires a population of around 34 million. When other lignocellulosic materials, such as paper and wood, are considered as feedstocks for ethanol production, a population of more than 6 million is needed to meet the input demand of the NREL's case. Note that the New York-Jersey City-White Plains, NY-NJ Metropolitan Division, the largest metropolitan statistical area in the US, had a population of 20 million in 2015, followed by the Los Angeles-Long Beach-Anaheim, CA Metropolitan Statistical Area (13 million) and Chicago-Naperville-Elgin, IL-IN-WI Metropolitan Statistical Area (10 million) (US Census 2016), so the NREL's design case could be practical in the New York, Los Angeles and Chicago metropolitan areas. However, ethanol production using solid waste in other areas might be feasible with small-scale plants, which may have lower ethanol yield and result in lower profits than the NREL's design case. Also, parametric assumptions may different from the design case. To address the inconsistency between the plant size and resource availability, further research on small-scale fuel production processes and waste resource logistics is warranted. Due to lack of information, however, assumptions for the ethanol fuel transportation and distribution are the same as the conventional ethanol transportation assumptions in the GREET model in this study. Transportation for waste feedstock is excluded in this analysis as in the $\mathrm{CNG}$ production processes. 


\section{RESULTS AND DISCUSSIONS}

In summary, WTW GHG emissions and fossil fuel consumption have been evaluated for two waste-derived fuel production pathways: $\mathrm{CNG}$ via $\mathrm{AD}$ and ethanol via fermentation. For CNG production, it is assumed that source-separated domestic food waste is processed in an anaerobic digester co-located at a landfill. The thermal and electric demands for the $\mathrm{AD}$ processes are supported through biogas combustion in CHP, and the remaining biogas is cleaned and upgraded to RNG. It is sent via pipelines to offsite refueling stations, where the RNG is compressed to CNG. Digestate (Class A biosolid) is utilized as fertilizer displacement with emissions and energy credits. In the case of ethanol production, yard trimmings waste is used as feedstock at an ethanol production plant co-located at a landfill. Residuals from the fermentation processes are combusted to meet onsite heat and power requirements. Produced ethanol is then transported and distributed.

Two different counterfactual scenarios are compared with the alternative fuel production: One is moderate LFG collection and the other is active. For both cases, we assumed that the collected LFG is flared. The landfills are assumed to be located at boreal and wet climate conditions.

\subsection{GHG EMISSIONS PER DRY TON OF WASTE BY WTE PATHWAYS COMPARED WITH COUNTERFACTUAL SCENARIOS}

Figure 6 compares the GHG emissions associated with the WTE projects using one dry ton of waste (renewable CNG via $\mathrm{AD}$ from food waste and ethanol via fermentation from yard trimmings) to those from treating the same amount of waste using the current waste treatment (counterfactual scenario). For landfilled food waste, GHG emissions are estimated at 2,336 and $1,604 \mathrm{~kg} \mathrm{CO} 2 \mathrm{e} / \mathrm{dry}$ ton of waste when it is landfilled in moderately and actively managed landfills, respectively. Yard trimmings waste has lower GHG emissions: 1,993 and 1,451 kg $\mathrm{CO}_{2} \mathrm{e} /$ dry ton of waste for landfills with moderate and active LFG collection cases, respectively. Note that food waste has larger GHG emissions per dry ton of waste than yard trimmings, mainly because of the lower LFG collection rate of food waste. The major GHG emissions source from landfilled waste is $\mathrm{CH}_{4}$ emission not captured by LFG collectors (gray bars in Figure 6) while the other two GHG emissions sources, such as LFG flaring emission (i.e., $\mathrm{CH}_{4}$ combustion emission in light blue bars in Figure 6), non-combustion $\mathrm{CO}_{2}$ emissions from waste decomposition and $\mathrm{CH}_{4}$ oxidation (green bars in Figure 6), are relatively small. Note that the moderately managed landfill generates substantially larger GHG emissions than the actively managed landfill does because of its lower LFG collection rates and high GWP of $\mathrm{CH}_{4}$. As shown in Table 6, only a fraction of the carbon in waste is emitted as non-combustion $\mathrm{CH}_{4}$ in the counterfactual scenarios. However, due to its high GWP, the contribution to the GHG emissions of the non-combustion $\mathrm{CH}_{4}$ is much greater than the other sources. 


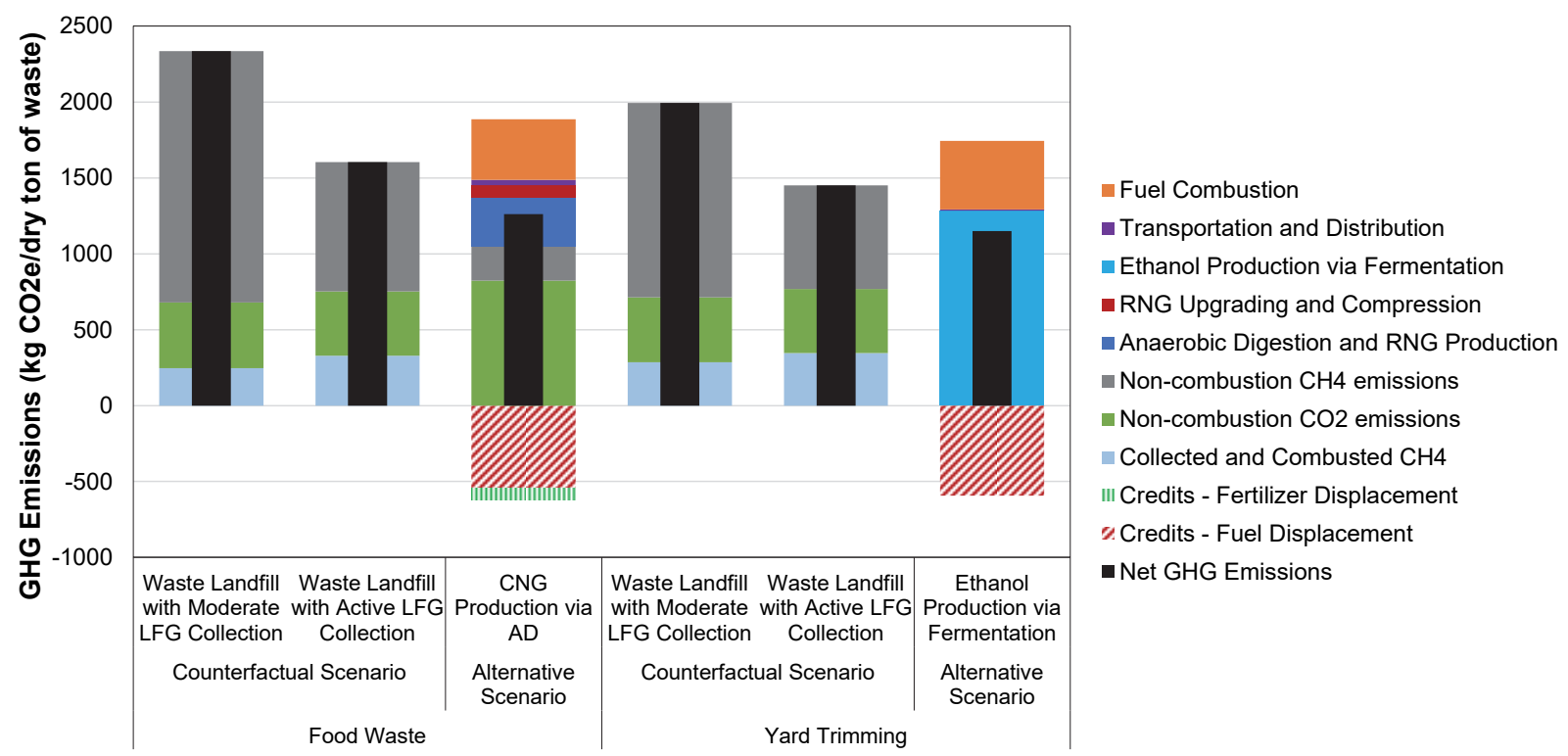

FIGURE 6 GHG Emissions for CNG from Food Waste AD and Ethanol from Yard Trimmings Fermentation Compared with Counterfactual Scenarios $\left(\mathrm{kgCO}_{2} \mathrm{e} /\right.$ Dry Ton of Waste Input)

TABLE 6 Carbon Fate from Waste and GHG Emissions Contribution by Each Stage in the Counterfactual Scenarios and the WTE Pathways

\begin{tabular}{|c|c|c|c|c|c|c|}
\hline \multirow[b]{2}{*}{$\begin{array}{l}\text { Food Waste to CNG } \\
\text { (kg/dry ton of waste) }\end{array}$} & \multicolumn{2}{|c|}{$\begin{array}{l}\text { Moderate LFG } \\
\text { Collection }\end{array}$} & \multicolumn{2}{|c|}{$\begin{array}{l}\text { Active LFG } \\
\text { Collection }\end{array}$} & \multicolumn{2}{|c|}{$\begin{array}{c}\text { CNG Production } \\
\text { via AD } \\
\end{array}$} \\
\hline & $\begin{array}{l}\text { C from } \\
\text { waste }\end{array}$ & $\begin{array}{c}\text { GHG } \\
\text { emissions } \\
\left(\mathrm{CO}_{2} \mathrm{e}\right)\end{array}$ & $\begin{array}{l}\mathrm{C} \text { from } \\
\text { waste }\end{array}$ & $\begin{array}{c}\text { GHG } \\
\text { emissions } \\
\left(\mathrm{CO}_{2} \mathrm{e}\right)\end{array}$ & $\begin{array}{l}\text { C from } \\
\text { waste }\end{array}$ & $\begin{array}{c}\mathrm{GHG} \\
\text { emissions } \\
\left(\mathrm{CO}_{2} \mathrm{e}\right)\end{array}$ \\
\hline Recovered and Combusted $\mathrm{CH}_{4}$ & 67 & 247 & 90 & 329 & & \\
\hline Non-combustion $\mathrm{CO}_{2}$ & 118 & 433 & 116 & 424 & 225 & 824 \\
\hline Non-combustion $\mathrm{CH}_{4}$ & 41 & 1,657 & 21 & 851 & 5.6 & 226 \\
\hline $\mathrm{AD}$ and RNG Production & & & & & 55 & 323 \\
\hline RNG Upgrading and Compression & & & & & 6.3 & $79^{\mathrm{a}}$ \\
\hline Transportation and Distribution & & & & & & $35^{\mathrm{a}}$ \\
\hline Fuel Combustion & & & & & 109 & 398 \\
\hline Carbon Sequestration & 204 & 748 & 204 & 748 & 32 & 117 \\
\hline Total Carbon from Waste & 431 & & 431 & & 431 & \\
\hline
\end{tabular}




\begin{tabular}{|c|c|c|c|c|c|c|}
\hline \multirow[b]{2}{*}{$\begin{array}{l}\text { Yard Trimmings to Ethanol } \\
(\mathrm{kg} / \mathrm{dry} \text { ton of waste })\end{array}$} & \multicolumn{2}{|c|}{$\begin{array}{c}\text { Moderate LFG } \\
\text { Collection }\end{array}$} & \multicolumn{2}{|c|}{$\begin{array}{c}\text { Active LFG } \\
\text { Collection }\end{array}$} & \multicolumn{2}{|c|}{$\begin{array}{c}\text { Ethanol Production } \\
\text { via Fermentation }\end{array}$} \\
\hline & $\begin{array}{l}\mathrm{C} \text { from } \\
\text { waste }\end{array}$ & $\begin{array}{c}\mathrm{GHG} \\
\text { emissions } \\
\left(\mathrm{CO}_{2} \mathrm{e}\right)\end{array}$ & $\begin{array}{l}\text { C from } \\
\text { waste }\end{array}$ & $\begin{array}{c}\mathrm{GHG} \\
\text { emissions } \\
\left(\mathrm{CO}_{2} \mathrm{e}\right)\end{array}$ & $\begin{array}{l}\text { C from } \\
\text { waste }\end{array}$ & $\begin{array}{c}\mathrm{GHG} \\
\text { emissions } \\
\left(\mathrm{CO}_{2} \mathrm{e}\right)\end{array}$ \\
\hline Recovered and Combusted $\mathrm{CH}_{4}$ & 78 & 286 & 94 & 346 & & \\
\hline Non-Combustion $\mathrm{CO}_{2}$ & 117 & 429 & 115 & 423 & & \\
\hline Non-Combustion $\mathrm{CH}_{4}$ & 32 & 1,279 & 17 & 682 & & \\
\hline Ethanol Production & & & & & 310 & $1,247^{\mathrm{a}}$ \\
\hline Imported Natural Gas & & & & & & $36^{\mathrm{a}}$ \\
\hline Transportation and Distribution & & & & & & $7.3^{\mathrm{a}}$ \\
\hline Fuel Combustion & & & & & 123 & 452 \\
\hline Carbon Sequestration & 207 & 758 & 207 & 758 & & \\
\hline Total Carbon from Waste & 434 & & 434 & & 434 & \\
\hline
\end{tabular}

a Carbon emissions from other resources are included, such as fossil fuel combustion and upstream emissions of chemicals inputs and imported electricity.

The results show that the WTW GHG emissions associated with the renewable CNG production pathway from food waste are $1,263 \mathrm{~kg} \mathrm{CO} 2 \mathrm{e} /$ dry ton of waste. Major sources of GHG emissions in the renewable CNG production pathway include non-combustion $\mathrm{CO}_{2}$ and $\mathrm{CH}_{4}$ emissions, emissions from AD and RNG production, upgrading, and compression, and fuel combustion emissions. Non-combustion $\mathrm{CO}_{2}$ emissions are calculated from the carbon balance, taking out the amount of sequestered carbon in digestate, carbon in combustion emissions, and carbon in non-combustion $\mathrm{CH}_{4}$ emissions from the carbon in the waste input. The results also show that the non-combustion $\mathrm{CO}_{2}$ emissions in the $\mathrm{CNG}$ production case are much larger than in the counterfactual scenarios, because digestate applied to soil is assumed to be decomposed through aerobic digestion, not $\mathrm{AD}$, leading to higher oxidation with low carbon sequestration. Non-combustion $\mathrm{CH}_{4}$ emissions in Figure 6 indicate only $\mathrm{CH}_{4}$ from digestate decomposition; the $\mathrm{CH}_{4}$ leakages are included in the AD and RNG upgrading category. Because the amount of digestate applied to soil is much smaller than the amount of landfilled waste, and the decomposition takes place under aerobic conditions, non-combustion $\mathrm{CH}_{4}$ emissions in the $\mathrm{CNG}$ production are significantly smaller than the massive uncontrolled $\mathrm{CH}_{4}$ emissions from landfills.

Note that fuel combustion emissions (orange bars in Figure 6) are offset by the credits from the displaced fuel. Because the fuel displacement credits (hatched red bars in Figure 6) include emissions from natural gas recovery to fuel combustion emissions at vehicles (WTW), this credit is $20 \mathrm{~g} \mathrm{CO}_{2} \mathrm{e} / \mathrm{MJ}$ of CNG larger than the emissions from fuel combustion alone (PTW). The digestate generated from the anaerobic digester is assumed to displace conventional fertilizers by mass of nutrients $(\mathrm{N}, \mathrm{P}$, and $\mathrm{K})$, which leads additional credits of $-80 \mathrm{~kg} \mathrm{CO} \mathrm{CO}_{2} \mathrm{e} / \mathrm{dry}$ ton of waste (hatched green bar in Figure 6). 
For ethanol produced from yard trimmings via fermentation, the major GHG emissions source is the process emissions (cyan bar in Figure 6), which are largely from biomass burning, although there is a small amount of emissions for NG, diesel fuels, and chemicals. Compared with the AD case, the ethanol production pathway has fuel displacement credit and fuel combustion emission of -594 and $452 \mathrm{~kg} \mathrm{CO} /$ dry ton of waste, respectively.

As shown in Table 6, the WTE pathways sequester less carbon and generate more carbon emissions (e.g., $\mathrm{CO}_{2}, \mathrm{CH}_{4}, \mathrm{CO}$ and volatile organic compound, etc.) to air than the counterfactual scenarios. However, by avoiding the uncontrolled $\mathrm{CH}_{4}$ emissions and displacing fossil fuels and fertilizers, the WTE pathways result in lower GHG emissions than the counterfactual scenarios. It should be noted that diverting waste from landfills with lower LFG collection efficiency provides even greater GHG emissions reduction. For example, if one dry ton of food waste is diverted from a landfill with moderate LFG collection to the WTE pathways, the GHG emissions reduction resulting from the diversion could be $46 \%$. On the other hand, when one dry ton of food waste is diverted from a landfill with active LFG collection, the GHG emissions reduction decreases to $21 \%$, because the avoided uncontrolled $\mathrm{CH}_{4}$ emissions in the counterfactual scenarios are much smaller with the landfill with active LFG collection. Similarly, for the ethanol production pathway, the GHG emissions reductions by diverting yard trimmings from the landfills with moderate and active LFG collection to the WTE pathway are estimated to be $42 \%$ and $21 \%$, respectively.

\subsection{WTW GHG EMISSIONS OF WTE PATHWAYS}

Because the fuels generated from waste are to be used as transportation fuels, they need to be compared with other fossil fuels such as petroleum gasoline and natural gas to investigate relative changes in GHG emissions and fossil fuel consumption. In such cases, WTW fossil fuel consumption and GHG emissions should be expressed in terms of energy in fuels. This is especially needed when one wants to assess WTE GHG effects under the California Air Resources Board's (CARB) Low Carbon Fuel Standard (LCFS) and EPA's RFS frameworks. As mentioned, marginal approaches consider only the differences between counterfactual scenarios and alternative scenarios. Because we assume that the alternative fuel production cases replace the current waste management practices in landfills, the energy consumption and GHG emissions associated with the landfill scenarios should be considered as the credits of the fuel production pathways.

Figure 7 represents the WTW GHG emissions of the CNG production and ethanol production cases in terms of $\mathrm{MJ}$ of fuel produced and used. As before, two counterfactual scenarios are considered for each alternative fuel production scenario - landfills with moderate and active LFG collection and flaring. When the GHG emissions of CNG from food waste are compared with those of fossil natural gas, the relative reductions are $157 \%$ and $28 \%$ with the moderate and active LFG collection scenarios, respectively. For the ethanol production pathway from yard trimmings with the moderate and active LFG collection scenarios, relative reductions compared with petroleum gasoline are $146 \%$ and $52 \%$, respectively. Like the GHG emissions 


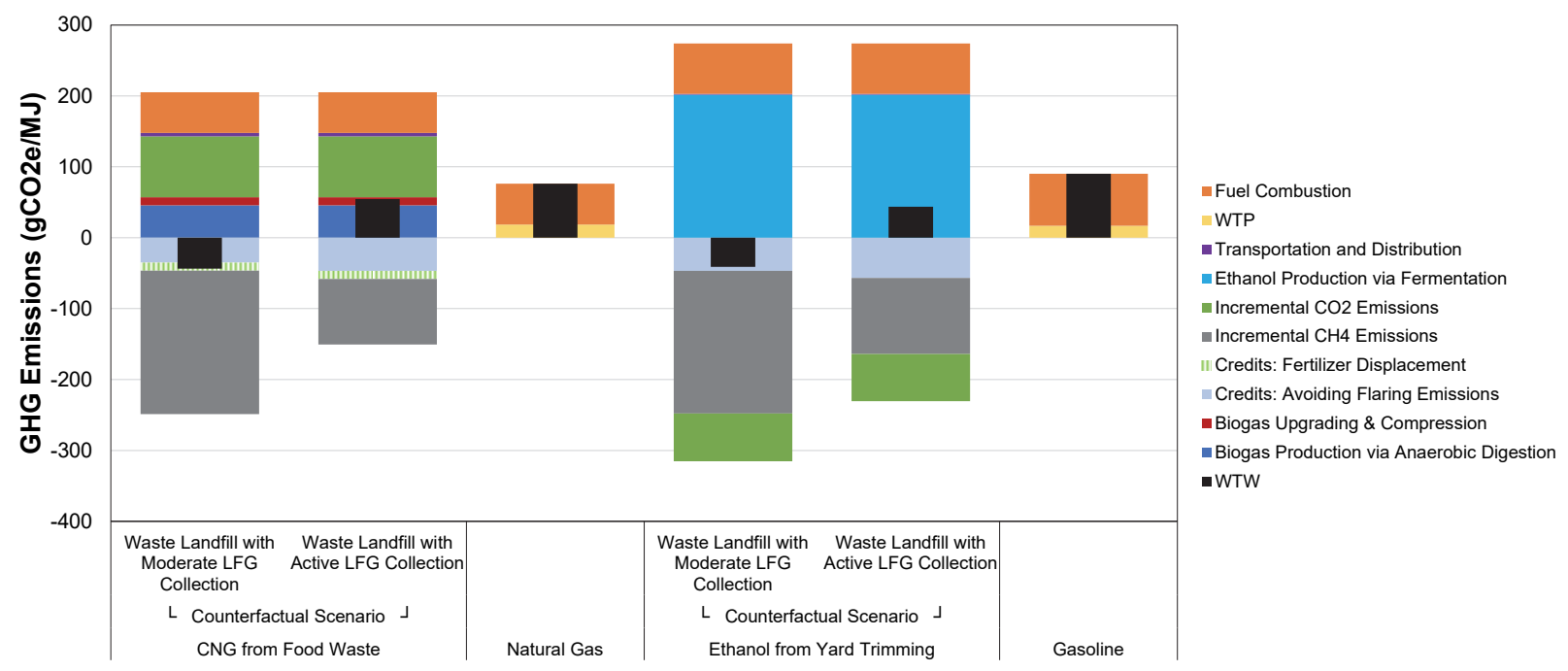

FIGURE 7 WTW GHG Emissions for CNG from Food Waste AD and Ethanol from Yard Trimmings Fermentation Compared with Conventional NG and Gasoline Pathways (g CO Produced and Used)

results per dry ton of waste, the reductions in WTW GHG emissions are significantly larger when the waste feedstock is diverted from the landfill with moderate LFG collection compared with those with active LFG collection.

Major reductions result from avoiding the emissions associated with the counterfactual scenario. Large $\mathrm{CH}_{4}$ emissions from landfills lead to huge credits, as shown in the negative incremental $\mathrm{CH}_{4}$ emissions (e.g., credits from the eliminated $\mathrm{CH}_{4}$ emissions) for all cases. For CNG production, there are positive incremental non-combustion $\mathrm{CO}_{2}$ emissions, because the landfill cases have higher carbon sequestration than the CNG production cases do. The ethanol production pathways mostly release carbon in the feedstock through combusting either waste feedstocks or fuels. This gives negative non-combustion $\mathrm{CO}_{2}$ emissions while having higher process emissions during ethanol production compared with the AD process.

\subsection{WTW FOSSIL FUEL CONSUMPTION OF WTE PATHWAYS}

Using renewable fuels reduces WTW fossil fuel use because renewable resources are primarily used in their production. Figure 8 shows WTW fossil fuel consumption for producing CNG from food waste through AD and ethanol from yard trimmings through fermentation, and the results are compared with those of petroleum gasoline and natural gas. Because the fuels generated from waste feedstocks are non-fossil based, they do not, unlike petroleum fuels, include fossil fuel consumption during fuel combustion (PTW), which reduces WTW fossil fuel consumption significantly. The results show that the $\mathrm{CNG}$ and ethanol production pathways from waste feedstocks use fossil fuels $-0.07 \mathrm{MJ} / \mathrm{MJ}$ and $0.30 \mathrm{MJ} / \mathrm{MJ}$, respectively. These reduce fossil fuel consumption by $106 \%$ and $74 \%$, compared with CNG and petroleum gasoline, respectively. Even during the fuel production processes, alternative scenarios mostly use renewable resources, 


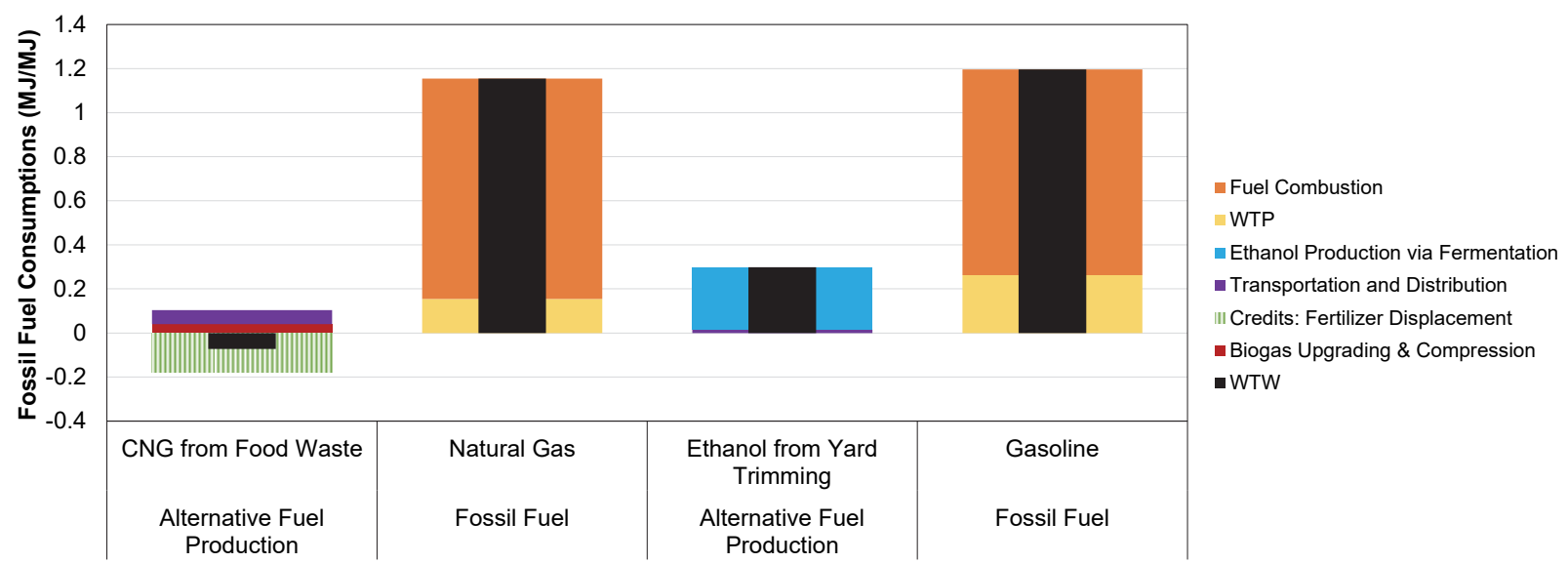

FIGURE 8 WTW Fossil Fuel Consumption for CNG from Food Waste AD and Ethanol from Yard Trimmings Fermentation Compared with Conventional NG and Gasoline Pathways (MJ/MJ of Fuel Produced and Used)

avoiding fossil fuel consumption. The waste-derived $\mathrm{CNG}$ production pathway uses biogas to operate the system, except for the compression process at offsite refueling stations and the transportation of digestate and fuels. Instead, the pathway earns credits for displacing conventional fertilizers such as nitrogen fertilizer, which is produced from natural gas, a fossil fuel source. Similarly, the ethanol production from yard trimmings mostly uses heat and power generated from biomass combustion, while only a small amount of natural gas and diesel fuel is used to support the process. 


\section{CONCLUSIONS AND DISCUSSION}

In this study, lifecycle fossil fuel consumption and GHG emissions of two fuel production pathways using solid wastes have been analyzed - CNG production pathways from food waste via $\mathrm{AD}$ and ethanol production pathways from yard trimmings waste via fermentation. Because wastes need to be managed even if they are not utilized for fuel production, the energy consumption and GHG emissions associated with current waste management practices can be avoided when the wastes are used for fuel production. Since most non-recyclable waste materials in the United States are disposed of in landfills, we assumed that the alternative fuel production scenarios displace landfilling of wastes. Thus, this LCA study considers the differences in the energy consumption and GHG emissions between the current landfilled waste practices (the counterfactual scenario) and the fuel production processes using solid wastes (the alternative fuel production scenario).

$\mathrm{CH}_{4}$ generation from landfills is estimated using a first order decay model, which calculates $\mathrm{CH}_{4}$ generation over time using parameters collected from actual landfills. It varies mainly by type of waste materials and climate conditions. Once LFG is generated, landfill operators are required by regulations to collect and flare the LFG produced to reduce environmental impacts. The LFG collection efficiency varies depending on the landfill's operation, such as cover installation, and the start and end of horizontal and vertical LFG collectors. In this study, two landfill scenarios have been considered, with moderate and active LFG collection, and in both cases the collected LFG is assumed to be flared. Despite the fact that around half of the degradable carbon in landfilled wastes stays in landfills, uncontrolled $\mathrm{CH}_{4}$ emissions from landfills increase the GHG emissions of the counterfactual scenarios significantly on a $\mathrm{CO}_{2} \mathrm{e}$ basis.

Data collected from literature and previous LCA studies have been used to simulate CNG production using food waste. For the $\mathrm{AD}$ processes, actual food waste $\mathrm{AD}$ data have been used, and $\mathrm{CH}_{4}$ leakages from various stages of $\mathrm{AD}$ and the processes of biogas upgrading and utilization were also considered. Ethanol production using yard trimmings has also been simulated based on the NREL's report on lignocellulosic fermentation for ethanol production. While ethanol yield per dry ton of feedstock is assumed to be the same regardless of types of feedstocks, process energy requirements were adjusted to allow for the differences in the moisture contents of the feedstocks.

The emissions associated with landfilled wastes were compared with those of wastebased fuel production pathways. When one dry ton of food waste is landfilled, GHG emissions are estimated at 1,604-2,336 $\mathrm{kg} \mathrm{CO}_{2} \mathrm{e}$. The range is caused by LFG collection rates under different landfill operation conditions. The low end represents landfills with active LFG collection, while the high end is for the landfills with moderate LFG collection. When the same amount of food waste is used for CNG production instead, GHG emissions are estimated at $1,263 \mathrm{~kg} \mathrm{CO}_{2} \mathrm{e}$, which is $21-46 \%$ less than that of the counterfactual cases. The major reductions come from fuel displacement credits and lower $\mathrm{CH}_{4}$ emissions compared with the landfill cases. Similarly, ethanol production pathways have $1,150 \mathrm{~kg} \mathrm{CO}_{2} \mathrm{e}$ emissions per dry ton of yard 
trimmings treated, which is $21-42 \%$ less than landfills, which generate $1,451-1,993 \mathrm{gCO}_{2} \mathrm{e} / \mathrm{dry}$ ton of yard trimmings.

In order to compare lifecycle energy consumption and GHG emissions with other transportation fuels, the results were also expressed in terms of energy in fuels. In these cases, the energy consumption and GHG emissions associated with the landfilled cases become credits for the alternative fuel production pathways because they are avoided by diverting the waste for the fuel production. The CNG production pathways reduce $28-157 \%$ of WTW GHG emissions on a MJ basis compared with production of $\mathrm{CNG}$ from natural gas, while the ethanol production pathways reduce $52-146 \%$ of WTW GHG emissions on a MJ basis compared with those of petroleum gasoline.

This study shows potential environmental benefits of utilizing solid wastes for fuel production instead of landfilling them. However, the results may vary greatly depending on the parameters affecting the LFG collection rate, such as the types of feedstock, climate conditions, and LFG collection strategy. These parameters used for simulating $\mathrm{CH}_{4}$ generation are highly uncertain and require further investigation. Nonetheless, the study shows the greater GHG reduction opportunities when WTE operations target landfills with low collection rates (and thus high GHG risks).

WTE pathways indeed are a way of waste management in place of landfills. Nationwide, a total of 10 million dry tons of food wastes and 5.4 million dry tons of yard trimmings were landfilled in 2013 (EPA 2015). If these wastes were used for energy production instead of landfilled, the challenge many cities and states face in expanding landfills to deal with future wastes could be avoided, in addition to the GHG and fossil energy benefits shown in this study. 


\section{REFERENCES}

40 CFR Part 98, Subpart HH. 2016. Electronic Code of Federal Regulations. Vol. Title 40: Protection of Environment PART 98-MANDATORY GREENHOUSE GAS REPORTING, Where: Accessed September 7. http://www.ecfr.gov/cgi-bin/text$\mathrm{idx}$ ?SID=05b64e27e76cda5c5a1705dbee63b2a2\&mc=true\&node=sp40.23.98.hh\&rgn=div6.

Argonne National Laboratory. 2015. "The Greenhouse Gases, Regulated Emissions, and Energy Use in Transportation (GREET) Model."

Banks, Charles J., Michael Chesshire, Sonia Heaven, and Rebecca Arnold. 2011. "Anaerobic Digestion of Source-Segregated Domestic Food Waste: Performance Assessment by Mass and Energy Balance.” Bioresource Technology 102 (2): 612-20. doi:10.1016/j.biortech.2010.08.005.

Barlaz, Morton A., Jeff P. Chanton, and Roger B. Green. 2009. "Controls on Landfill Gas Collection Efficiency: Instantaneous and Lifetime Performance." Journal of the Air \& Waste Management Association 59 (12): 1399-1404.

California Air Resources Board. 2016. "Method for Estimating Greenhouse Gas Emissino Reductions from Diversion of Organic Waste from Landfills to Compost Facilities." California Air Resources Board. https://www.arb.ca.gov/cc/waste/cerffinal.pdf.

Han, Jeonwoo, Marianne Mintz, and Michael Wang. 2011. "Waste-to-Wheel Analysis of Anaerobic-Digestion-Based Renewable Natural Gas Pathways with the GREET Model." Argonne National Laboratory (ANL). http://www.osti.gov/scitech/biblio/1036091.

Humbird, David, Ryan Davis, Ling Tao, C. Kinchin, D. Hsu, Andy Aden, P. Schoen, et al. 2011. "Process Design and Economics for Biochemical Conversion of Lignocellulosic Biomass to Ethanol: Dilute-Acid Pretreatment and Enzymatic Hydrolysis of Corn Stover." http://www.nrel.gov/docs/fy11osti/47764.pdf.

IPCC. 2006. “2006 IPCC Guidelines for National Greenhouse Gas Inventories.” http://www.ipcc-nggip.iges.or.jp/public/2006gl/vol5.html.

Lee, Uisung, Jeongwoo Han, Meltem Urgun-Demirtas, Michael Wang, and Ling Tao. 2016. "Lifecycle Analysis of Renewable Natural Gas and Hydrocarbon Fuels from Wastewater Treatment Plants' Sludge.” ANL/ESD-16/19. Argonne National Laboratory.

Mintz, M., J. Han, M. Wang, and C. Saricks. 2010. "Well-to-Wheels Analysis of Landfill GasBased Pathways and Their Addition to the GREET Model." Argonne National Laboratory (ANL). http://www.osti.gov/scitech/biblio/982696.

SCS Engineers. 2008. "Current MSW Industry Position and State-of-the-Practice on LFG Collection Efficiency, Methane Oxidation, and Carbon Sequestration in Landfills." Prepared for 
Solid Waste Industry for Climate Solutions (SWICS) 2. http://consulteffect.com/wpcontent/uploads/2015/03/FINAL_SWICS_GHG_White_Paper_07-11-08.pdf.

Spokas, K., J. Bogner, J. P. Chanton, M. Morcet, C. Aran, C. Graff, Y. Moreau-Le Golvan, and I. Hebe. 2006. "Methane Mass Balance at Three Landfill Sites: What Is the Efficiency of Capture by Gas Collection Systems?" Waste Management 26 (5): 516-25. doi:10.1016/j.wasman.2005.07.021.

US Census. 2016. "Metropolitan and Micropolitan Statistical Areas." https://www.census.gov/popest/data/metro/totals/2015/index.html.

US EPA. 2012. "Resource Conservation and Recovery." EPA-430-R-09-044. Washington, DC. https://www.epa.gov/sites/production/files/2015-

08/documents/resource_conservation_and_recovery_a_guide_to_developing_and_implementing greenhouse_gas_reduction_programs.pdf.

US EPA. 2015. "Advancing Sustainable Materials Management: 2013 Fact Sheet.” http://www.epa.gov/epawaste/nonhaz/municipal/pubs/2013_advncng_smm_fs.pdf.

US EPA. 2016. "Inventory of U.S. Greenhouse Gas Emissions and Sinks:1990 - 2014.” EPA 430-R-16-002. https://www3.epa.gov/climatechange/Downloads/ghgemissions/US-GHGInventory-2016-Main-Text.pdf.

US Government Publishing Office. 2010. Mandatory Greenhouse Gas Reporting. Electronic Code of Federal Regulations. Vol. Title 40: Protection of Environment: http://www.ecfr.gov/cgibin/text-

idx?SID=fb5716ea193141 c6658e 7232d69e880c\&mc=true\&node=pt40.21.98\&rgn=div5\#sp 40.2 1.98.hh. 



\section{Argonne}

\section{Energy Systems Division}

9700 South Cass Avenue, Bldg. 362

Argonne, IL 60439

www.anl.gov 